\title{
The Bacchic-Chor(a)ic Chronotope:
}

\section{Dionysus, Chora and Chorality in the Fifth Stasimon of Sophocles' Antigone}

\section{Introduction: Time and Space in Greek Tragedy}

Greek drama is the ideal test case for the study of time and space in Greek myth. As its literary, poetic, or, better said, performative frame is linked to a specific place and occasion, i.e. Athens at Dionysian festivals, the genre occupies that realm between literacy and orality. The tragic poet composes a script designed for a single performance at a specific time in front of a known Athenian audience in the theatre of Dionysus. The chorus assigned by the polis to the poet plays a decisive factor, representing a group surrounding and yielding space to the professional actor. To a certain extent they express a "together with" sensation that shapes the space with reference to other figures and creates the deeper intellectual and emotional matrix that mediates between the actors and the audience. ${ }^{1}$ The entire theatrical setting of the theatre of Dionysus involves a complicated structure of spatial enclosures. The audience of ten to fifteen thousand people, more than a third of the male citizenship of the entire polis, grouped on the north-western slopes of the Acropolis encloses the orchestra where the chorus sings and dances, encircling the skene that constitutes the lower back stage where the actors perform - it all embraced by the majestic landscape of the steep Acropolis at the audience's back and the Attic landscape behind the skene reaching to the sea at the horizon. ${ }^{2}$ A festive time of exception, a brief moment, characterizes time. The outer frame also influences the play itself so that we can speak of an oscillating exchange between inner-dramatic and extra-dramatic perspectives. In the dramatic plays, time is subordinated to space: the fictive time situated in the mythic past, the plots taken from episodes in the mythic megatext emerging from the oral principles of variation and selection, a great network weaved together over a long process. ${ }^{3}$ Plot variations are allowed as

1 Haß and Tatari 2014, esp. 81; Nancy 2014, esp. 108; Haß 2014. On the Greek chorus, see Bierl 2001, esp. 11-104 (Engl. 2009, 1-82).

2 On the theatrical space in general, see e. g. Wiles 2003; Kramer and Dünne 2009.

3 See Segal 1983, esp. 176; Segal 1986, esp. 52-53. 
long as the basic structure remains recognizable. Weaving with mythic fabric, the tragedians perpetuate this collective work while also prompting the audience to reflect upon contemporary political events. The stories can zoom in and out of Athens and her actual situation, the chorus as a polyphonic instance serving as a shifting and mediating tool in this regard. ${ }^{4}$ All things considered, the tragic plot takes place during a relatively short period of time. Since practically everyone knows the mythic outcome from the beginning, little emphasis is placed on narrative progress, step-by-step analysis or suspense produced by temporal evolution. ${ }^{5}$ From the start the actors and the chorus act as if everything were already pre-determined; usually the outcome is already revealed in the prologue or shortly thereafter. ${ }^{6}$ The chorus can glide back to preceding times, jump to the future or zoom-in into the present of the actual performance, creating special effects of presence.

Space, the other basic Kantian category, dominates. The play is situated in a mythic locale. As has been pointed out, Thebes represents the place of the Other, ${ }^{7}$ where all categories and distinctions collapse. Many tragedies are located there while Athens, the place of the performance, is widely avoided. We can define an axis of decreasing Otherness: Thebes, or some distant barbarian region, housing the Other; Argos, Delphi, and Sparta representing a middle ground, and Athens functioning as a mirror of Athenian identity - even in mythical times it is the least othered. ${ }^{8}$ Dionysus, the honoured god intrinsically linked to drama, can be understood as the deity of the Other. ${ }^{9}$ Typically his place of birth is Thebes, but we also have indications for Thrace, Phrygia and Lydia. Yet he can also facilitate, via zooming, a perspective of the here and now, of the actual performance in his honour at the Athenian theatre. Furthermore, the chorus can project itself onto numerous places: it can intone other landscapes, reaching near and far on a horizontal axis, traveling from the Underworld to the sky on the vertical axis. Moreover mythic time and space interact with ritual reenacting myth in cul-

4 Sourvinou-Inwood 1989, esp. 136, 138, 144; on the fluidity of choral voices and the chorus as shifter, see Bierl 2001, esp. Introduction; see Index Chor / 'Fluktuation (Ambiguität) der Instanzen und Rollen' (Engl. 2009); see also Gagné and Hopman 2013b, 1-28.

5 Nancy 2014.

$6 \mathrm{Haß} \mathrm{2014,} 143$.

7 Zeitlin 1990.

8 Zeitlin 1990; Zeitlin 1993. On Dionysus in tragedy from Thebes to Athens, see also Bierl 1991, 45-110.

9 Gernet 1953, 393 was the first to interpret Dionysus as “the Other”. See also Vernant 1965, 358; Vernant 1981, 18; Vernant 1983, 42-43; Vernant 1985, 246; Vernant 1986, 291-292. See Bierl 1991, 15-16 and Gödde 2011, 85-88. 
tic terms while myth itself creates a scenario of distorted forms of violence and anti-culture.

\section{The Concept of Chronotope}

Time and space always interfere with each other in specific configurations. For chronological and spatial interconnected structures in literature the Russian formalist and classicist Mikhail Bakhtin (1895-1975) coined the term, and theory of, chronotopes. His concept, on the one hand, is rather ahistorical and abstract, taken from mathematics and the theory of relativity, yet, on the other hand, he attempts to link certain chronotopes to real-life experiences. For some genres and epochs, the chronotopes boil down to objects of motifs. His analysis of the chronotope of the ancient novel became well known. He argues that the primary dimension is space, whereas the temporal axis moves almost against the zero-point. The adventure time that perpetuates itself in the plot of the erotic novels has very little effect on history or processes drawn from everyday life, least of all on the biological time of the heroes, who do not undergo any kind of maturation or mental development. ${ }^{10}$ Even in the field of the ancient novel, critics rehabilitated the temporal axis. Be it as it may, the tragic chronotope obviously favors space over time as well.

The purely literary approach was recently complemented through the exploration of several chronotopes in competition with each other. Richard Seaford discusses chronotopes in tragedy as matrices of social behaviour. In the vein of Émile Durkheim, he sees them in terms of models for a cognitive perception of the world and as social constructions based on socio-economic and cultural achievements. According to Seaford, various chronotopes operate in the tragic text as if in a battleground. Like in the Hegelian or Marxist evolutionary model of three steps, one stage evolves into the next one to reach the final solution. The reciprocal chronotope of Homeric time comes under attack after the invention of money, leading to the unlimited or monetised chronotope. From this internal conflict, a reintroduction of communal ritual in the new aetiological chronotope emerges. Tragedy mirrors the socio-historical evolution in the progression from unlimitedness to limitedness played out in the institutionalization of a final ritual. ${ }^{11}$

10 Bakhtin 1981, 84-258; on the ancient novel, see Bierl 2006, esp. 73 (Engl. 2014).

11 Seaford 2012, esp. 1-10, 11-121. On Antigone, see 327-332, on the fifth stasimon, 331. 
Deeply influenced by his model and teacher, Lucas Murrey draws upon Seaford when emphasizing the role of mysteries in tragedy. In a book on Hölderlin, whose translations of Greek tragedy inspired his new hymnic poetry, he develops an internal three-step evolution based on mystic ritual of three sub-chronotopes from the so-called "Dionysiac chronotope". Disoriented by an overpowering and absolute limitlessness, the initiate overcomes the crisis of death to experience complete unity. Thus, like in a rite de passage, the unlimited chronotope, which he extends to visual and abstract thought, facilitates a near death experience from which the ordered, limited chronotope emerges, one equal to Seaford's ritualistic and aetiological chronotope. Moreover, he connects the unlimited, monetised sub-chronotope to the visualized chronotope. In this framework he explores how the visual and the audible are captured in tragedy and modern reception. ${ }^{12}$ The Dionysian, as Murrey points out, reveals itself in the distorted utterances of fear and horror as well as in the vocal cry of liberation and the specific visual experiences acting out this moment of limited unity. ${ }^{13}$

Departing from my previous work on Dionysus, I will introduce a Bacchicchor(a)ic chronotope, ${ }^{14}$ which will not be based on socio-cultural construction and internal development, but instead it will focus on the concrete moment of eruptive energy as an expression of chorality. It is thus punctual instead of extensive in the sense of a rite of passage or an internal conflict of different stages. Thus, in a way, it is not constructive diachrony but pure, aesthetic synchrony.

\section{Dionysus as God of the Other, Ambivalence, Mediation, Performance and Presence}

Before we can further pin down the chronotope we must first endeavor to define the god behind it. Dionysus' dazzling ambiguity fascinates us more than ever in these (post)postmodern times. Like a kaleidoscope he constantly oscillates between manifold manifestations. Therefore the elusive god resists clear-cut and simple definitions. ${ }^{15}$ As a multi-faceted, ambiguous and transgressive deity,

12 Murrey 2015; on the "Dionysiac chronotope", see esp. 9-23. On the fifth stasimon of Antigone, see 55.

13 Murrey 2015, 37-60 (with examples taken from Greek tragedy).

14 Bierl 1991; Bierl 2011a; Bierl 2011b; Bierl 2013a.

15 The following passage and few other parts are based on Bierl 2012. On the role of Dionysus in all three dramatic genres, see Bierl 2011a. On the following description of the god, see Bierl 2011a, 315-316 and Bierl 1991, 13-20. On some basic ideas about Dionysus as the personification of the ecstatic performance, see Ford 2011, esp. 347-355; Bierl 2012; Bierl 2013b, esp. 36. On 
full of energy and abounding vitality, Dionysus is always on the move and in constant flux. He notoriously exposes others to transformations within a range of categorical oppositions. Dionysus occupies the "in-between" between oppositions, simultaneously present on both sides, which, understood as energetic forces in dynamic reciprocation, tend to fuse under his influence. He is not only the violent, ecstatic and destructive power, but also the central urban deity stabilizing society. It is well known that myth and ritual complement each other. Myth encompasses scenarios of inversion and violence, while cult embraces phenomena of group cohesion like festivity, enjoyment and happiness. In the realm of Dionysus, however, myth and cult cannot be neatly separated. Ritual reenacts myth and myth mirrors ritual. Taking everything into account, it makes the most sense to assert Dionysus as the figure of the Other, also in the Lacanian sense, since he epitomizes difference more than any other Greek deity. ${ }^{16}$ Most of all, he tends to show his liminal presence when displaying his whole array of signification. We constantly encounter him as arriving from afar or even from the realm of the dead, manifesting himself in his manifold forms

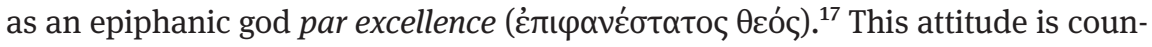
terbalanced by scenarios of resistance which he must overcome through miracles and other spectacular manifestations.

Among his main features and areas of responsibility we can name: 1 . wine and inebriation; 2 . wild nature, vegetation and animality; 3 . madness and ecstasy; 4. the Underworld and death; 5. mysteries and afterlife; 6. sex and eroticism; 7. dance, music and performance; 8. mask and costume; 9. fiction, imagination, vision and miracle. ${ }^{18}$ The last three items establish his role as the god of theatre. A community assembled in a $\theta \dot{\varepsilon} \alpha \tau \rho o v$ watches the spectacle or show $(\theta \dot{\varepsilon} \alpha)$ of a procession bringing the deity into the city, ${ }^{19}$ a celebration of the arrival of "the

Dionysus in tragedy, see Bierl 1991; on the chorus, also often in a Dionysiac context, see Bierl 2001 (Engl. 2009). On Dionysus in general, see Henrichs 1982; Henrichs 1996a; Schlesier 1997. On Dionysus as a different god, see the volume by Schlesier 2011.

16 See Gernet 1953, 393 and above n. 9.

17 See the inscriptions of Antiochia CIG III 3979 und CIG 1948 (named together with the chthonic epithet Eubouleus; see the gold leaf from Thurii fr. 491.2; see also fr. 488.2, 489.2 and 490.2 Bernabé = 5-7 Graf and Johnston); on Dionysus' particular presence and tendency to show himself in an epiphany, see Otto 1933, esp. 70 - 80; Henrichs 2008, 19; Henrichs 2011.

18 See Henrichs 1982, esp. 139; Henrichs 1996a, esp. 479; Henrichs 2008, esp. 23; Schlesier 1997 (esp. C: “Wirkungsbereich”; Engl.: Dionysus. Brill’s New Pauly. Brill Online, 2013. Reference. Universitaetsbibliothek Basel. 29 January 2013 <http://referenceworks.brillonline.com/entries/brills-new-pauly/dionysus-e320270>).

19 See Kavoulaki 1996 (she does not include Soph. Ant. 1115-1152). 
coming god". ${ }^{20}$ Dionysus can function as a $\theta \varepsilon \alpha \tau$ In (spectator), masked actor or even the leader of his ritual chorus that celebrates him with song and dance, we also find him among his entourage of mythic female maenads and male satyrs occupied with the same performative activities. The procession, $\theta \varepsilon \omega \rho i \alpha$ or $\pi о \mu \pi \eta$, serves as a matrix for drama that evolves from further choral expansions. These xopoí were performed after the reception of the god in the city centre and eventually evolved into theatre performed with the polis as audience. As the coming god Dionysus bridges the fixed boundaries of time and space, old and new, past, present and future, absence and presence, inside and outside, here and then, death and live, beneath and above. Dionysian chorality helps create a performance of blurring perspectives mediating between myth and ritual, dramatic action and cultic framing as well as time and space with regards to the mimetic-representational, the imaginary and the pragmatic here and now of the Athenian theatre of Dionysus. In his epiphanic quality of deus praesentissimus, ${ }^{21}$ manifesting himself through performative means, Dionysus becomes the emblem of the new thinking of presence in mediality upon which we have embarked following the excesses of poststructuralism. ${ }^{22}$

Upon this background the Bacchic choric chronotope takes shape. Intense Dionysian songs featuring this chronotope happen often at decisive turningpoints, moments of metabole or even peripeteia, moments of choral self-referentiality often paired with choral projection. ${ }^{23}$ Theatre reflects theatre in a metatheatrical manner. ${ }^{24}$ The chronotope is positioned at transitions, at the boundaries, those in-between points of liminality where myth and ritual fuse and the categories of time and space blur.

At these moments of epiphany and choral manifestation, tragedy becomes aesthetic form and pure performance. ${ }^{25}$ Medium, so to speak, becomes the message: ${ }^{26}$ A sudden, miraculous expression of a holy time and place in synaesthe-

20 See Otto 1933, esp. 74-80; on the "kommende Gott" as a Romantic concept (G.F. Creuzer, F. Hölderlin [see Brot und Wein, line 54]), see Frank 1982 and Henrichs 1984, 216-219.

21 See Ov. Met. 3.658-659: nec enim praesentior illo / est deus. See Henrichs 2011, esp. 105.

22 On the new era of medial presence, see Kiening 2007a and the contributions collected in Kiening 2007b.

23 On Dionysiac choral self-referentiality, see Segal 1982, 242-47; Bierl 1991, e.g. 35-36, $83-$ 84, 99, 106-107, 129, 155, 164, 190 -191, 224, 242-243 (where Dionysus is associated with self-referential and metatheatrical utterances) and Henrichs 1994/1995. On choral projections, see Henrichs 1994/1995, esp. 68, 73, 75, 78, 88, 90.

24 Bierl 1991, 111-119 and Bierl 2001, 43 - 44 (Engl. 2009, 29-30).

25 For modern poetry, these phenomena are well described by Bohrer 2015.

26 See McLuhan's 1964, 23 famous sentence “The medium is the message”. 
sia that extends onto the cosmic; ${ }^{27}$ eruptive energy in ecstasy, often associated with fire, pure music and dance, pre-linguistic noise and cry. The chronotope is hybrid, permeable to the extra-dramatic instance of utterance, a shifting zone between inside and outside, ritual and myth. It mediates like the chorus, its hallmark. ${ }^{28}$ Ekstasis is combined with enthousiamos; full of the god and medial noise, one steps out of the usual individuality. The subjective person melts with the community. In Attic theatre, Dionysus manifests himself in performance, rituality and choreia, that is, in wild cries, in theoriai and pompai, accompanied by the shrill melody of the aulos, the wild rhythm of tympana and ecstatic dance and choral movement, while often specific groups or persons vehemently oppose him in mythical terms.

Mania mediates between the deity of frenzy and his entourage. The maenads set the god in frantic movement in the same way that he, as their choral leader, is responsible for the choral and multimodal performance of his group. This results in the typical fusion and oscillation of perspectives. The god, to some extent, embodies the pure, semiotic voice of the cultic devotees. Epithets like Bók-

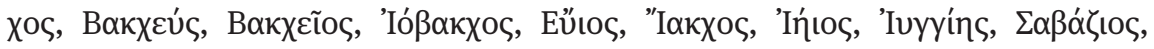
envision the god as the personification of the inarticulate cries delivered in short and iterated combinations, such as bakch-, eua-, eui-, iakch-, ie-, iy-. ${ }^{29}$ The lack of propositional meaning entails an instantiation of "poetic function" according to Roman Jakobson. ${ }^{30}$ The utterance in lyric frenzy tends to reference only itself, the performative eruption of energy. Such self-contained moments narrate little, but employ highly ritual forms similar to lyric poetry with a tendency to reference their own chorality and performativity. If any proposition exists, it amounts to myth that frames the ritual.

Already in another publication, I have described how the fusion of word, music and rhythm achieves both an emotional intensity and an insidious loss on the level of signification. ${ }^{31}$ Both performers and spectators experience a sense of integrative unity, cohesion and inner meditative centering. The Bacchic chronotope conveys the subjective impression of being included in a greater whole, a feeling of oneness with the cosmos among the performers and partici-

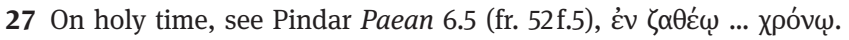

28 Gagné and Hopman 2013a, esp. Gagné and Hopman 2013b, esp. 1-28.

29 See Versnel 1970, 16-38, esp. 27-34; on Iacchus, see Graf 1974, 51-66. On the entire argument, see Ford 2011, with a reference to the poetic dimension, 355.

30 Jakobson 1960, esp. 358 [= Selected Writings III, 27]. See Tambiah 1985, 165 and Bierl 2001, 287-299, esp. 293 with n. 503, 331-346, esp. 335 with n. 92 (Engl. 2009, 254-265, esp. 259-260 with. n. 503, 296-310, esp. 299 with n. 92). See Bierl 2013b, 36.

31 Bierl 2001, 293-299 (Engl. 2009, 259-264). 
pants. Furthermore, I tried to give an account of the effects in cognitive and neurobiological terms. In spillover effects, the flow of stimuli from parts of the central nervous system is diverted to other regions that contain vegetative and sensory centres as well as centres responsible for integrated thought and imagination. The performers (as well as the responsible god) thus become the transmitters and receivers of a message. ${ }^{32}$ This paradoxical communication sit-

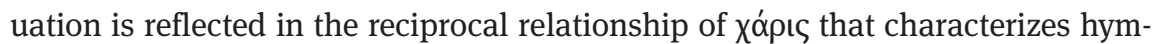
nic discourse. Ritual thus proceeds on the basis of two mutually complementary and asymmetrical systems. In such excited song and dance, the frontal cortex of the brain, the sensory centres of the cerebral cortex, the left and right hemispheres of the brain and finally hierarchically constructed levels of cortical and subcortical, endocrinal and immunological structures, are stimulated in an energy-creating (ergotropic) or energy-retaining (trophotropic) exchange. ${ }^{33}$

As said, Dionysus displays similarities to Lacan's Other, that is the unconscious, associated to the desire, and this desire of the Other produces language, images, music and dance in the symbolizing process of signification. According to Jacques Lacan, the ego only deceives itself into believing in an individual unity through imaginary means, in opposition to the real. In an intersubjective web, it succumbs to the symbolic, to an alienated Other or Id. It is encoded in linguistic signs on the basis of chains of signifiers by way of the supplementarity in the tropological play of metaphor and metonymy. ${ }^{34}$ The human worshipers are separated from God and desire the Other's presence. Close to death, but also abounding in energy, vitality and mystic union, Dionysus constitutes a special form of the Other. Desiring to close the gap between oneself and the deity, this desire, to some extent, becomes the Other's desire, the adoring chorus and spectators engage in symbolic utterance constitutive of a continuous gliding, a "glissement incessant du signifié sous le signifiant", ${ }^{35}$ which closes the gap between themselves and the Other, creating its imaginary presence.

32 See Tambiah 1985, 145 and 154. On the gods as the ultimate causal impetus behind phenomena experienced in the ritual process, see d'Aquili and Laughlin 1979, 170-171.

33 D’Aquili and Laughlin 1979, 172-180.

34 See Alexiou 2002, 151-171 and Bierl 2007, 255-258.

35 Lacan 1957 (= 1966, 502); Engl. Lacan 2006, 419 ("incessant sliding of the signified under the signifier”); see also Bierl 2006, 85-86. 


\section{The Concept of Chora}

At the same time, the space enclosing the Bacchic choros in the Other's epiphany and gliding utterance can be associated with the famous chora described in Plato's Timaeus (48e-53c). This space proves notoriously elusive, difficult to grasp, a "third species" ( $\tau$ ítov ... yévos 52a) situated between the ideal forms and their copies (mimemata) in the phenomenological world. Somehow it is the unconscious Other, to be understood only "through bastard logic" ( $\lambda$ oyı $\mu \tilde{\omega}$... vó $\theta \omega$

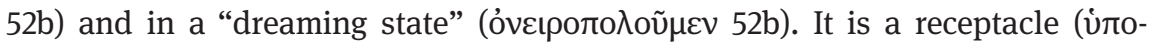

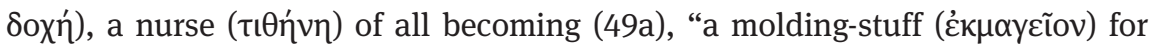
everything, being moved and marked by the entering figures" (50c), a wax-material without imprints, a medium, a substrate and catalyzer bringing forms into being and rendering becoming understandable. It possesses only traces (' $x \vee \eta$ 53b) of the form. It is the space in and from which fire appears as the fiery inflamed or water appears as substance liquefied and drinkable (51b, 52d). It is a "helper" (ßonӨós 52c) to make things manifest. God needs to approach this mediating space to effectuate his epiphany (53b).

These quintessential features also describe Dionysus, who suddenly manifests himself in fire and water; born from the maternal womb burned by Zeus' lightning close to the river Ismenus, Dionysus is, in a way, the catalyzer, the medium situated between the worlds, becoming present in his elements. Between man and woman he represents the maternal and creative, working as nurse via vibration and motion. The chora as receptacle serves as a winnowing sieve

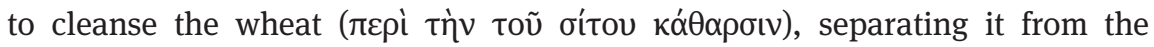
chaff, or respectively in a figurative sense, shaking the particles and bringing them into visible formations (52e). ${ }^{36}$ Shaking the body means kinesics and dance, thus choreia. Dancing belongs to Dionysus who shakes the ground with his feet. Etymology and new studies emphasize the connection between $\chi \omega \omega \rho \alpha$ and xopós. ${ }^{37}$ Choros also means the dancing floor, and chora is again the space enclosing the choros, where the group of dancers performs, communing with the divine, and from where its vital energy is processed and made present as choreia. Their alleged Indo-European common root * gher- is the place where this is made possible due to the arrival of a god. According to Julia Kristeva, chora is the feminine, erotic and emotive space linked to the body and materiality, and is thus creative. As it has to do with sensation, mood and memory, it is

36 On modern readings of the passage, see Casey 1997 and Sallis 1999.

37 See Chantraine 1968, 12 - he identifies * gher- as common root, "a place to which something/ someone goes or is taken” (Boedeker 1974, 86); see also Boedeker 1974, 85-91; McEwen 1993, esp. 41-78. 
socially connected and in touch with the people captured as a body. The depiction of the state in Plato's Timaeus is complementary to the purely mental and cold construct of Republic. Kristeva argues that magic, carnival, creativity, mystic shamanism and poetry are situated in the chora. It is creative as well as a method, a different beginning or form of procedure, an inventio in the sensational space. Its signification revolves from the symbolic, logocentric, abstract language back to the purely semiotic, that is language as voice, cry or pre-linguistic emotive language. ${ }^{38}$ Other critics emphasize the gliding logic, the creativity through an associational network woven like a traversing choros on the dancing floor. Its narrative logic is neither linear nor progressive but it loops both backwards and forwards. It is the place of traces, of emergence, and furthermore a space of memory, of the lively past reenacted for the future. ${ }^{39}$ As François de Polignac has shown, chora is also the concrete space around the city, the countryside perimeter of about 5 to 8 miles around the asty and city centre, the location of many shrines, temples and processions. It represents the space where the holy is situated, moving along bipolar axes to and from the city, being the transforming receptacle where the city's potential energy and vitality are grounded. ${ }^{40}$ Just to find the right designation, a name, for this elusive phenomenon is aporetic. Chora retracts itself constantly and gives way to new borderline reasoning,

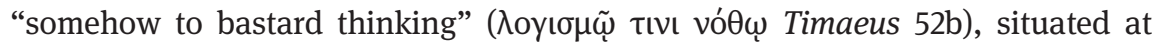
the edge. ${ }^{41}$ The place again recalls its constitutive god Dionysus, who produces paradoxical logic of the third kind. Particular confusion lies in his subjectivity, his shifting identity as theatrical persona, between "I" and "you". ${ }^{42}$ As is well known, his mask is his face - he constantly eludes our grasp with mimetic reenactments.

To summarize, chora is a matrix and space in which the idea of the Other is transformed into choral energy, it is a substrate of creative and poetic invention. In Attic theatre, Dionysus becomes particularly present when passing through chora, the container of the unconscious, paradox and ambiguous Other. All three, chora, choros and Dionysus as the decisive deity, mediate between stages, are situated in an in-between zone, making energy erupt. The semiotic overload

38 Kristeva 1984, see also the analysis by Rickert 2007, 260 - 263.

39 McEwen 1993; on a more abstract level, see Derrida 1983; Derrida 1995, esp. 89-127. On Derrida, see Rickert 2007, 263-267.

40 Polignac 1995, esp. 21-88. As Cursaru 2014 underlines, in Greek tragedy $\chi \omega ́ \rho \alpha$, i.e. space as $\chi \tilde{\omega} \rho{ }^{\prime}$ in the specific and restricted sense, designates the "'territorialized' identity" (113) of a polis based on religious and political discourses of authority.

41 See Derrida 1983; Derrida 1995, esp. 89-127.

42 Nagy 2013, 582-585. 
creates fusion and flows through excess; oppositions collapse. Chora is the receptacle, the space into whose centre the god is led in procession and where he becomes present and epiphanic via choral energy.

\section{The Parodos of Euripides' Bacchae and Philodamus' Delphian Paean}

To develop a truly Dionysiac foil of comparison, I will quickly explore the parodos of the Bacchae (64-166) as it paradigmatically displays the Bacchic, choral and choraic chronotope. In a recent article, ${ }^{43}$ I argued that the epiphanic god's arrival is realized and experienced as choral multimediality in an incoming procession ( $\pi о \mu \pi \eta ́)$. The Bacchic chorus, as a mediator, can cross boundaries, enhancing the quintessential tendencies of fusion in the realm of Dionysus. In the arrival zone, the entrance of the god in song and dance breaks the resistance to the god typically built in the mythic constellation. The retained energy is transformed in the chora and released in an all the more violent manner through the god's entourage. In terms of inner-dramatic events, the parodos functions as an interface for the further course of the play, where the arrival in the city of Thebes and the expulsion of the opponents into the mountains simultaneously represents the transition to the brutal events on Mt. Cithaeron. After all, the chorus of Lydian Bacchae, as a theatrically and aesthetically confusing ensemble, becomes the energetic message, set in a mise en abyme, in the rhythmical and ritual performance. Most of all, through choral projection, the movement toward the inside simultaneously and paradoxically becomes one toward the outside, integrating perspectives into the past and future. ${ }^{44}$ Thus, the dimensions of time and space, as well as other oppositions, blur in a ritual flow of choreia and performativity. Past, present, future and the actual, cultic time of performance fuse. Furthermore, the space and time of myth are reenacted in the ritual of drama. Multiple loops create a sensation of unity and communitas in the liminal 'anti-structure'. ${ }^{45}$

In Bacchae we indeed have two choruses: the actual chorus of Asian devotees, i.e. the Bacchae, and the internal, imaginary offstage chorus, so in fact three choruses, of Theban women, who, having been chased to the mountains,

43 See Bierl 2013a; see also Bierl 2011b (in German). See also Kavoulaki 1999.

44 Segal 1982, 78-124, esp. 87 and 245 recognizes that the centripetal force of the inside will be inversed by the centrifugal dynamics of the outside.

45 On communitas, see Turner 1974, esp. 274 (definition); on anti-structure (in relation to communitas), esp. 45, 46, 50, 272-298. 
brutally kill Pentheus, tearing him apart and eating his flesh raw. Semele's three sisters become their virtual choral leaders. The aristocratic women who opposed Dionysus become, by his intervention, cultic followers of the god, that is, wild maenads, perverted ritual bacchants acting out the mythic drama of revenge against the resistance. This second Theban chorus is only imagined offstage in the imaginary space, in the zone beyond the chora of the wild mountains created by narration. The audience in the orchestra never sees it, but the chorus on stage dances and sings, just reflecting and at best spurring on the actions of the other chorus.

In short, Dionysus punishes his city through his own ritual, performative and theatrical means. The Lydian worshippers praise Dionysus in عủoĩ-cries (151), the Euios, the, so to speak, divine embodiment of the ecstatic shout (157). The maenads project themselves onto Mt. Cithaeron in a wildly iterated

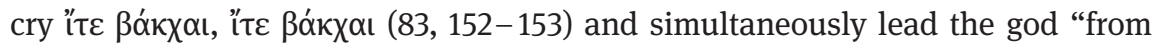

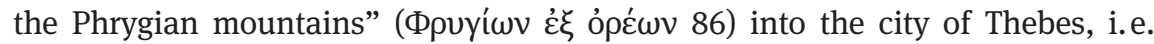

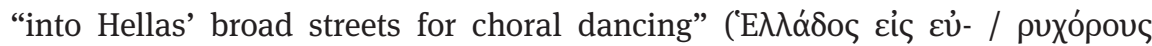
óyviós 86-87). In the eyes of the chorus Dionysus represents their chorus leader,

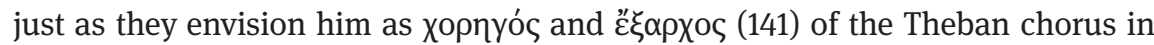
the mountains. ${ }^{46}$

In the typical manner of total fusion and reciprocity between performance and space, the chora which Dionysus enters is often imagined in a state of frantic

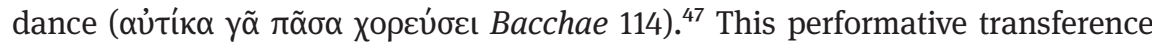
to the natural environment underlines the all-encompassing epiphany. We witness a similar totalizing effect, the projection of chorality onto nature, countryside or polis space, in the Delphian paean of Philodamus of Scarphea, ${ }^{48}$ lines

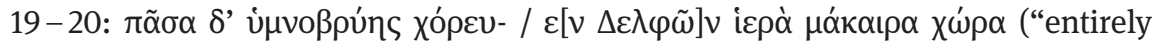
full of hymns danced the sacred and blessed land of the Delphians"). This happened when the god was born in the past and then he returned to Thebes (lines 5-17). But especially at his first stop on his tour in Delphi "he himself made his

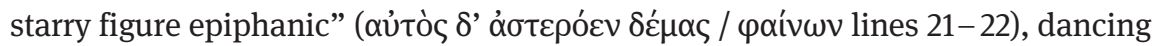
with Delphic maidens on Mt. Parnassus (lines 18-26). In the same way as he had appeared in Delphi in the past with choral celebrations, the group once

46 Dionysus is often notionally envisaged as a virtual divine choregos or exarchos, see Bierl 2001, 42, 144 n. 101, 145, 147-148 (Engl. 2009, 29, 120 n. 101, 122-124). Numerous passages associate Dionysus with the action of ôyeıv - such as in Eur. Bacch. 115, or in the choral projections on Mt. Olympus (Bacch. 412-413) and on Mt. Pieria (Bacch. 566-570) - both are linked with Euius.

47 See Bierl 2001, 147-148 (Engl. 2009, 123) on Ar. Thesm. 995-1000; Kowalzig 2007.

48 Powell 1925, 165-171 and Furley and Bremer 2001 I, 121-128; II, 52-84. 
again calls upon itself to receive Dionysus, the Paean and Saviour, in a proces-

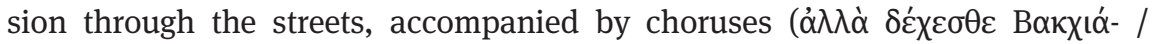

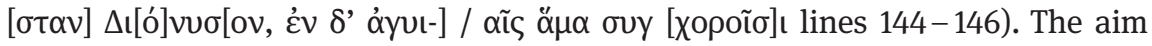
is to make him present there through sacrifice and choreia. From his birthplace Thebes he proceeded to Delphi, the first stop on his tour. He is then envisaged in Eleusis, where he is celebrated as mystic Iacchus, full of light in a pannychis (lines 27-36), and later in Thessaly and Pieria before he is summoned to come back to Delphi again. Thus linear movement and procession alternates with a circular loop and with cyclic dance, the dithyramb (line 133-134, 151), through that he should become epiphanic again in Delphi at the new temple, his final destination, so to speak. ${ }^{49}$ Moreover, his statue ( $\alpha \beta \gamma \alpha \lambda \mu \alpha$ line 137), according to a command by Apollo, is to be drawn into the temple precinct, "attractive, like the bright beams of the rising sun" (lines 136-137) to be later erected watching "over the sacrifice and competition of many dithyrambs" (lines 132134). The beautiful image, the statue, alternates with his true epiphany in choreia (lines 133-134, 144-146). It is as if the agalma, exchangeable with its god, could somehow become animate. It is a well-known fact that this hymn, composed around 340 BC, draws heavily on the fifth stasimon of Sophocles' Antigone and on the parodos of Euripides' Bacchae.

The latter, the ritual entrance song of the chorus of the Bacchae, blends in episodes of Dionysus' mythical beginning glossed over by Philodamus (lines 6-10). The aetiological myths of Dionysus's birth - the death of Semele, Zeus' thigh-pregnancy (Bacchae 94-98) and Dionysus' second birth (99-104) - justify his special divine authority and the ritual power. At the same time, in reciting the birth myth, the Bacchants underline the processional entrance in a metaphorical and iconic manner. This is, so to speak, the image of the maternal chora set in a mise en abyme, the female poetic invention put in mythic narration sung by the choros. Violence and energy twice erupt from a bodily enclosure, first from Semele's womb, then Zeus' thigh. The city gate, the female womb and the thigh represent the resisting boundaries, which the baby as well as the Bacchic group must rupture. The ecstatic cries that interrupt the syntax represent the semiotic potential of Dionysus Bromius, the Roarer. He represents the pre-linguistic intersubjective desire of unity and thus of the Other. In the Bacchae we can see how the phantasma of an integral subject falls in pieces. According to Lacan, the decentered ex-istence of man is constituted on language, chains of signifiers produced in the tropological play of metaphor and metonymy. Returning to the linguistic turn based on Ferdinand de Saussure and Roman Jakobson,

49 On circular dances, see Ant. 59, 124, 133-134. 
Lacan argues that human beings close the opened gaps to the Other, to Dionysus, in a gliding signification process, thus overcoming the experience of sparagmos through poetry and choral dance in order to create the illusion of an integral self. In the Bacchae, Euripides self-referentially unveils this psychoanalytical and anthropological truth and, in the same way, closes the gap in poetic language and religious mysticism. The play exhibits the sparagmos of the man who opposes Dionysus, the Other, and the recomposition of his body. Dionysian phantasmagoric unity is conveyed in poetry taking place in the Bacchic-choric chronotope of chora, a place of liminality, of transition, the boundary to death. It is not only the zone in which the Other is brought in and acted out in ecstatic choral dance, but also where the opposing forces are mediated, interacting in a violent eruption of energy and media presence.

\section{Sophocles' Antigone}

Despite the prevalence of political and philosophical interpretations in a Hegelian vein, Sophocles' Antigone is a deeply and intrinsically Dionysian tragedy. ${ }^{50}$ This must not automatically lead to a Nietzschean reading. Antigone is hardly a Dionysian figure in Kerenyi's sense, who takes the heroine as such because "the cruel touch of death arouses the liveliest life". ${ }^{51}$ Yet death plays the crucial role in all interpretational attempts. Without knowing Lacan's famous interpretation in his Seminar VII, held in 1959-1960, ${ }^{52}$ I emphasized Antigone's association with Dionysus, especially in relation to her one-sided, almost incestuous relationship with her dead brother Polyneices. ${ }^{53}$ Antigone's uncompromising attitude toward death links her decisively to Dionysus, who embodies the dichotomy of life and death and has a special relationship with Hades. Lacan sees the special relation through a spatial lens. It is therefore vital to make up leeway and include his thoughts in our discussion of the Bacchic-chor(a)ic chronotope. ${ }^{54}$ According to Lacan, Antigone is situated at the boundary between life and death, on the edge of the so-called "second death", a place defined also by symbolic

50 See Kerényi 1935; Bierl 1989; see also Heinrich 2002.

51 Kerényi 1935, 14. Deeply inspired by Nietzsche, Kerényi (1935, 13-14) perceives tragedy in general as a Dionysian experience, in the respect that the tragic nearness of death inspires lust for life. This is the premise for his interpretation (14-19) of Antigone.

52 Lacan 1992, 243-287. On secondary literature, see Miller 2007 and Buchan 2012.

53 Bierl 1989.

54 On Antigone and chora, see already Randhawa 2014; on Dionysus as instance of the semiotic and on the fifth stasimon, see 304-306, 310. 
absence. She is driven by a yearning for death. Her liminal position as a suffering, martyr-like hero on the edge of death, fire and ate makes her beautiful, rendering her appearance most beautiful, as if she were hit by an arrow of desire that makes her gleam. She emblematizes her yearning for death, a radiant

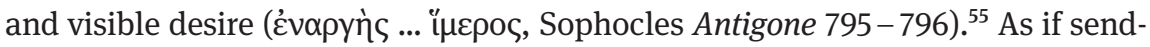
ing out a double of herself immune to destruction, she hovers between life and death and in this in-between status she glows with beauty. Like a saint, she administrates the boundary to the desire, becoming its focus. ${ }^{56}$ Gliding on the edge of language, between the being and that which has being, in Heidegger's terminology, she succumbs to signification ex nihilo, beyond the usual linguistic process, uttering just semiotic cries of lament in tautological manner. This makes her appear a mystified virgin, close to the Other, who must sacrifice her being. ${ }^{57}$

In a quasi-procession Antigone enters the cave where she is immured alive. This is her position at the second death, and through her suicide she finally transcends the boundary to Hades. In this liminal zone, the Bacchic chora, particularly in the fourth and fifth stasima, Dionysus will transform into pure energy and fire and subsequently force Antigone to find her destiny, the end of her course. ${ }^{58}$ Her death in beauty is cathartic. ${ }^{59}$ Like Dionysus and his chronotope, she is positioned in the liminal and synchronic-circular, in a zone of metabole and transition. It is a matrix of mediation and catastrophe, of catharsis through mania and ecstasy.

\section{The Fifth Stasimon of Sophocles' Antigone}

In the famous fifth stasimon of Sophocles' Antigone (1115-1152), my main example that I will treat in much more detail, the chorus conjures up the Dionysiac landscape through which to send the god once more, processionally, to his homeland Thebes. ${ }^{60}$ The plot of Antigone reaches its dramatic climax at this

55 See Lacan 1992, esp. 262-269.

56 See Lacan 1992, esp. 257-262.

57 See Lacan 1992, esp. $270-283$.

58 Nagy 2013, 593-594 stresses Dionysus' epiphany in fire ("he literally ignites the singing and the dancing as he leaps out, in an elemental burst of flame, from inside the fennel stalk or narthêx" [593]) and links it with an Indo-European concept of a god emerging from a reed with lightning, smoke and fire. Lacan 1992, 268-269, 281-282 touches the fourth and fifth stasima.

59 See also Lacan 1992, 243-247.

60 See Jebb 1900, 198-205; Müller 1967, 242-250; Kamerbeek 1978, 186 -190; Griffith 1999, 313 322; Brown 1987, 214-217; Furley and Bremer 2001 I, 301-304; II, 272-279; see also, among others, Kerényi 1935, 17; Vicaire 1968, 358-365; Winnington-Ingram 1980, 110 -116; Burton 1980, 
stage, coming to the decisive turning point, the peripeteia. A powerful arc builds until the end of the song, then drops off sharply at the catastrophe's revelation. After a long and obstinate refusal, Creon cedes to Teiresias' warnings. He is finally ready to bury Polyneices' body and to release Antigone from her natural prison. Creon hopes that he can still avert fate after Teiresias prophesizes the king must pay for his injustice towards Antigone with deaths in his own family (1064-1086). Quickly, but too late, he retreats from his wrong deed and orders Antigone freed from her rocky tomb and Polyneices buried (1108-1114). Tragically, Creon's men embark first on the latter order (1196-1204a) so that they arrive too late to save Antigone, who has stepped over the threshold of death. At this point, however, the chorus places all hope of salvation on its god. The Dionysiac excitement of the god's ecstatic worship transfers, ultimately, to the audience. The author directs the audience's emotions in such a way that the imminent upheaval, when it comes, produces maximum tragic effect; casting it all as an illusion intensifies the sudden plunge into the catastrophe - originated in the god's dark, Theban side - for both the chorus and the audience.

The chorus of Theban old men sings the following song:

\begin{tabular}{|c|c|}
\hline & 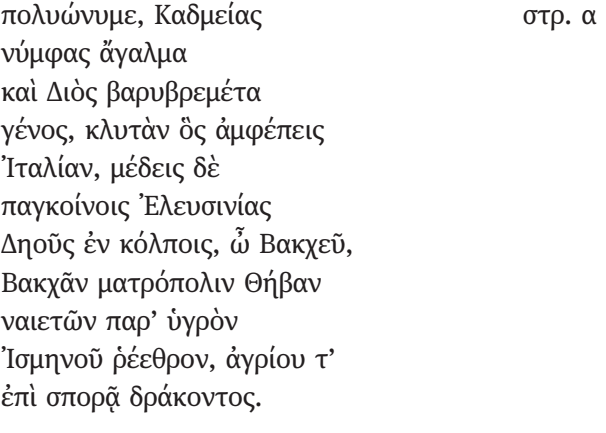 \\
\hline
\end{tabular}

132-135; Rohdich 1980, 209-214; Segal 1981, 200 -206; Oudemans and Lardinois 1987, 151-159; Bierl 1989, 50 -54; Bierl 1991, 127-132; Henrichs 1990, 264-269; Henrichs 1994/1995, 77-79; Scullion 1998; Cullyer 2005; Jouanna 2007, 116-132; Kitzinger 2008, 62-70; Ford 2011, 347348; Macedo 2011; Rodighiero 2012, 152-165; Jiménez San Cristóbal 2013, 276 - 279. 


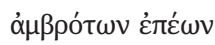

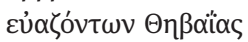

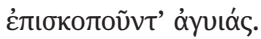

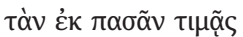

$\sigma \tau \rho . \beta$

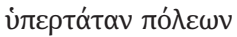

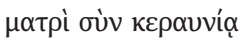

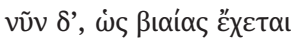

1140

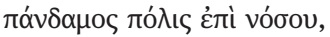

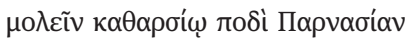

1143

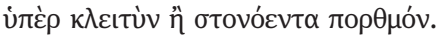

¿̇̀ $\pi \tilde{u} \rho \pi v \varepsilon o ́ v \tau \omega v$

$\dot{\alpha} v \tau . \beta$

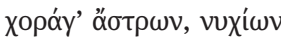

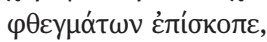

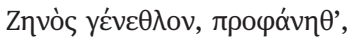

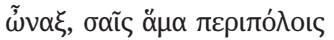

1150

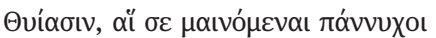

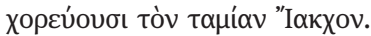

You of many names,

glorious image of the Cadmeian bride,

son of loud-thundering Zeus

you who watch over renowned

Italy and rule

in the folds of Eleusinian

Deo that are open to all, o Baccheus,

dwelling in Thebes, the mother-city of the Bacchae

beside the liquid

stream of Ismenus and over

the seed of the savage dragon.

You the flashing, smoky flame

has seen over the twin peaks

of rock where Corycian Bacchic

nymphs move (in dance),

and the spring of Castalia (has seen you).

And you, the ivied slopes

of Nysean mountains and the green shore

with many grape clusters send,

while immortal words

shout out their euoi-cry, as you are

overseeing the streets of Thebes,

that of all cities you

honour as preeminent, together

with your mother who was struck by lightning.

Now, since the city and its entire people

are held fast under wild sickness, 
come with purifying foot across the slope

of Parnassus or the moaning strait.

Io, chorus leader

of stars breathing fire, overseer

of voices in the night,

child, offspring of Zeus, appear in an epiphany,

lord, together with your attendant

1150

Thyiads, who in maddened frenzy the whole night long

set you in dance, the dispenser Iacchus.

The hymnos kletikos addressed to Dionysus for epiphany ( $\pi \rho \circ \varphi \alpha ́ v \eta \theta^{\prime}$ 1149) retains the typical style of an aretalogy, with all the wealth of formulas that go with it. ${ }^{61}$ In the end, the song withholds release but opens up the Bacchic chronotope, the chora as receptacle and a special, intense moment of holy time, facilitating the god's arrival. Poetry creates a vivid landscape of transition. It is the space from where Bacchus moves from afar to the centre of the here and now of Thebes, becoming present to the Athenian audience as well. As catalyst, the chora is able to transform the abstract and symbolic Olympian idea to pure energy responsible for bringing tragedy to its terrible end. It is the time and space where the boundary to fierce fire and death will be transcended. The god of tragedy becomes epiphanic as the elemental and cosmic power at the edge between life and death, while Antigone embarks on her final way, stepping over the

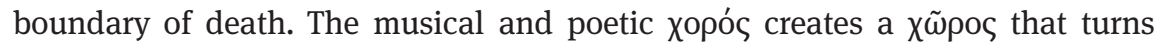
out to be a $\chi \omega \dot{\omega} \rho \alpha$, a space like a nurse and female womb, where mimemata are born from abstract forms. The mimetic chorus invents its own time and space where logos and abstract idea transform to fire and pure energy. It is the matrix and receptacle where voice, movement and vital energy outdo Creon's logos and purify from it.

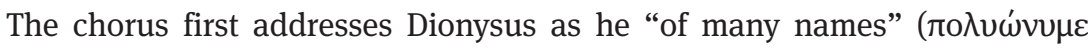
1115 ) in order to attract his attention, ${ }^{62}$ as if it were afraid to forget one. Naming is a notorious problem in symbolic language. ${ }^{63}$ With the catch-all formula, the chorus first avoids a precise name and the god, as a result, is not reduced to one specific idea but slowly emerges in the poetic chora. At the same time, of course, in the hymnic manner clear epitheta and geographic places accumulate

61 See Norden 1913, 143-177.

62 In Aegina he is even called غ̇лńкоoৎ, “the listener” (SEG XI.4). On Dionysus’ names, see Bierl 2013b.

63 This problem haunts also Derrida 1983 and esp. Derrida 1995, 89-127 in regard to chora and from a poststructuralist perspective. 
and, in relative and participial constructions as well as in you-predications, ${ }^{64}$ the god is called upon. Just as chora is notoriously difficult to name - it is a so-called a "third term" and follows a "bastard logic" (Plato Timaeus 52a-b) -, the chorus appears hesitant to name elusive Dionysus, who defies clear definition. The chorus seems aware of the aporetic status between signifier and the signified. The god, as the Other, can be captured only in traces (53b), through oneiric, unconscious logic (52b). Only some lines later in the hymn does the chorus devise the solution of applying just the names Bakcheus and Iakchos that lack any proposition or signification and are just the result of the cries of the followers. ${ }^{65}$ Possessed by the god, and in frenzy, the singers themselves bear the name Bakchoi, just as his mythical female entourage are called Bacchae. Contact with the deity is established by singing a long chain of signifiers through which the chorus tries to bridge the gap of desire for the presence of the Other. In praising Dionysus, they imagine him at rest in possible cult sites from where he might hasten to the aid of his threatened polis, Thebes. As "coming god", ${ }^{66}$ who prefers to manifest himself, ${ }^{67}$ we see him in a blossoming landscape returning home as in a procession (pompe) - in the first antistrophe the places actually send him ( $\pi \dot{\varepsilon} \mu-$ $\pi \varepsilon \mathrm{l} 1133)$ home. As a triumphant leader of the pompe, Dionysus oversees Thebes'

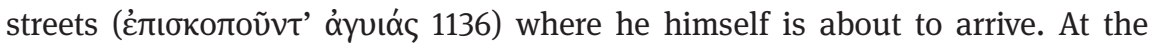
same time shouts of divine and inarticulate words, lacking again any proposi-

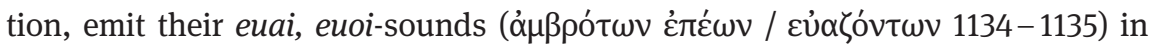
jubilation - a bold trope typical of the Dionysian style and chronotope. ${ }^{68}$ The acoustic song and speech elements are seen as active instances that perform an action, i.e. they shout euhoe or euie, euie. In their enigmatic meaninglessness of ecstasy, the words become divine in the same way that the god embodies the cry. Thus he becomes manifest without being actually present, and supervises the procession in the streets that fuse with the Athenian procession of the arriving god as agalma (1115). This first specifying noun is consciously kept ambivalent. He is the "pride" and "glory" of Semele, the Cadmeian bride - the mother, as is typical, is addressed first in this female chora -, and the "offspring, son"

64 See Norden 1913, 158 and Dorsch 1982, 66-75.

65 Ford 2011, 348 argues that the adjective polyonymos could be "hinting at the confusion such confusion can engender, giving the element the sense it has in polythrooos or polyglossos for overabundant, even confusing speech".

66 See above n. 20.

67 See above n. 17.

68 Usually persons shout euoi. Therefore, some textual critics missed the cultic followers as a

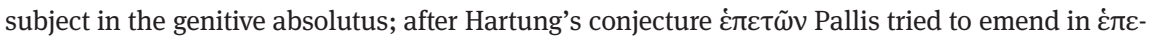

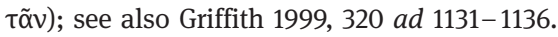


(1117) of Zeus. In this first apposition, his genealogy is recalled: it is the famous myth of Dionysus' premature birth on the banks of the river Ismenus, when Zeus' lightning torched Semele, who wished to see Zeus in his true form; the premature fetus was then put into Zeus' thigh for the second birth. Fire and water are thus the focus in the first strophic pair. But agalma can also mean the statue that is brought into the city through the procession. He is addressed as divine image of the elusive god that comes from Semele and Zeus. Zeus is deeply roaring ( $\beta \alpha \rho v$ $\beta \rho \varepsilon \mu \varepsilon \dot{\tau} \alpha$ 1116) because of the thunder that accompanies the lightning, just as his son is a loud Roarer (Bromios). Choral song creates first the image of the quintessential divine dancer in arrest, the phantasmagoric simulacrum, whereas later on in the song Dionysus will be captured as an activating, frantic performer,

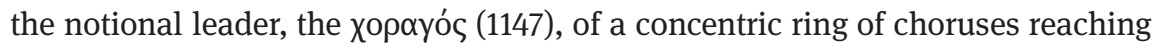
even to the cosmic sphere of the stars. This work of wonder (thauma) is a statue of great beauty, almost the Lacanian “sublime object”, existing for the gaze. Only in others' mind does it become vivid, animated, as if put in motion. In an illuminating contribution on the "metachoral" quality of dancers as artifices, Tim Power compares the choral statuary agalma to the Lacanian concept of the object petit a (= autre). ${ }^{69}$ From the object of monumental beauty desired in gaze emanates a phantasmagoric quality of magic enchantment. The small autre (other) stands in Dionysus' case for the big Other. Besides the progressions from the local to the universal and cosmic, from myth to cult and performance, from many to one name, from the afar to the here and now, ${ }^{70}$ we can also speak of a culminating movement from the artificial object in arrest towards energetic movement. The statue of the god is brought toward the centre, to Thebes, in a linear procession that culminates in a circular movement in the sky; the fixed image becomes more alive so that the god, interchangeable with it, separates itself from the artifice and acts as quiet spectator of the arrival of his own cultic procession until he changes into the activating agent, dancing and leading others, including nature and objects in choral kinetics.

In a typical relative clause with a you-predication, Dionysus is praised for watching over renowned Italy and reigning over the folds and valleys of the Eleusinian Deo/Demeter $(1117 \mathrm{~b}-1121) .{ }^{71}$ The female landscape resembles a bosom or

69 Power 2011, 89.

70 See Macedo 2011.

71 On the argument in support of the manuscript tradition 'I $\alpha \lambda \lambda^{\prime} \alpha v$ (1119), on account of its allusion to the mystery cult there, see the scholion; see Henrichs 1990, 267-269 and Burkert 1987, $142 \mathrm{n}$. 55. In order to limit the horizon and focus on Euboea and Attica, featured prominently in the song, various conjectures were put forward: Oix $\alpha \lambda \lambda^{\prime} \alpha v$ by Dawe 1979 in his Teubner edition of

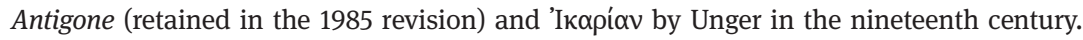


the folding of the womb, both common and open to all. Dionysus clearly assumes the role of Hades, and solid evidence indicates that around $500 \mathrm{BC}$, in some areas, Dionysus adopted the traits of an underworld deity. ${ }^{72}$ Already the hymn hints at his chthonic aspect through the Italian reference (1119) and his representation as the Eleusinian Iacchus/Dionysus (1119b-1121 and 11461154), though to be sure only in the purely positive light of the Eleusinian cult. Both the Dionysian mysteries of the Orphic circle in Southern Italy, and later in Magna Graecia, and the belief in Eleusis, whose adherents associated Dionysus as Iacchus with Demeter and Persephone, ${ }^{73}$ are distinguished by rites in which the initiates somehow experienced being near Hades. ${ }^{74}$ And clearly, Antigone possesses a special affinity towards Hades. ${ }^{75}$ In a transferred sense, Dionysus is both led in and leads Antigone to death, which also falls within the invoked realm of Iacchus' responsibility (1152), who in Aristophanes' Frogs must lead the Eleusinian initiates to the realm of the blessed. ${ }^{76}$ Italy and Eleusis stand for the mystic aspects of salvation that underline the expressed hope. ${ }^{77}$

72 A general discussion, esp. of the archaeological evidence as well, is found in Metzger 1944/

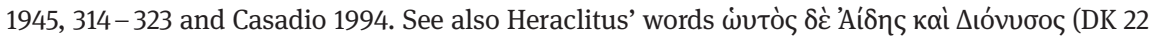
B 15) that allude to Dionysus' associations with the chthonic underworld, with the realm of death and the hope of an afterlife. These traits are particularly strong in Bacchic-Orphic mystery cults. See esp. the bone tablets from Olbia (463 Bernabé), dated to the fifth century BC, with the

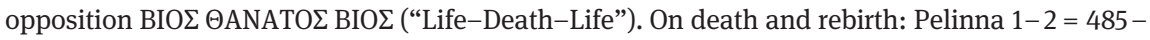
486 Bernabé $=26$ a und b Graf and Johnston, line 1: "Now you have died and now you have come into being".

73 On Iacchus, see Versnel 1972, 23-29 and Graf 1974, 43 and 46-69. In the mystery cult of

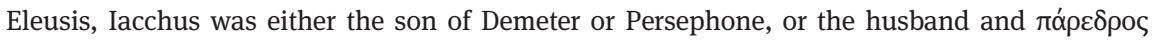
of Demeter. The complete identification of Iacchus and Dionysus emerges in the fifth century in Soph. TrGF IV 959; Eur. Ion 1074-1086, Bacch. 725-726; Philodamus Paean, lines 27-36; and schol. Ar. Ran. 404.

74 On Italy and the mysteries there, see the lamella from Hipponion (474 Bernabé = 1 Graf and

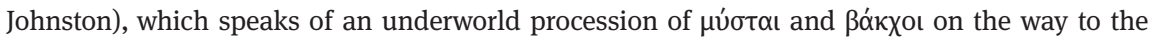
fields of eternal bliss (esp. lines 15-16); see also Burkert 1987, 22 and 142 n. 49. As comparison, the Eleusinian initiates celebrate a feast in Hades in Aristophanes' Frogs 440-459; see Graf 1974, 79-94 and Dover 1993, 250-253 ad 440-459. On the experience of Hades in Eleusis, see Burkert 1983, 279-280. According to Burkert 1987, 22, the Mysteries of Dionysus, esp. those in Southern Italy, can be seen as an adjunct to Eleusis. This equivalence in the mystery cults is reflected in the already-mentioned reference to Italy (1119); see Burkert 1987, 142 n. 55. On the Italian-Eleusinian mystery aspects of the song, see Henrichs 1990, 264-269.

75 Antigone's affinity with death is expressed as desire. The chorus explains her behaviour

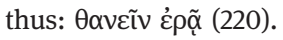

76 See Ar. Ran. 351-353, 403, 408, 413.

77 The text is highly ambivalent and ironical, shifting between concrete salvation from death and salvation in the mystic sense. The chorus and perhaps the audience hope that Antigone 


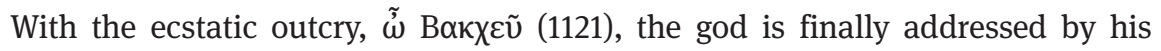
name, Bakcheus. In a way, the god emblematizes the energy conveyed in the

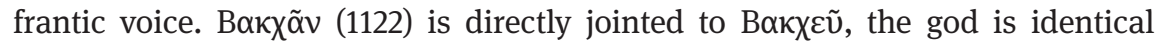
with his female followers filled with him and his cry. Instead of the relativeclause, the chorus continues now with an attributive participle to complement the predication: "inhabiting the mother-city of the Bacchants" (1122-1123). Again the female side is emphasized. Thebes is his mother-city and not his fatherland, and he dwells "beside the liquid streams of Ismenus ... on the soil of the seeding of the wild dragon" (1123-1125). Next to the fire, Dionysus is associated with the element of water. Moreover, in his motherland, where he should arrive in procession, the soil has not received the usual seed but the teeth of a slain dragon, a mythical allusion to the horrible violence intrinsically linked to his city. While the first strophe envisions the god on a route from the West to his birthplace - or, to some extent, in the eyes of the audience in Athens, the place of the actual performance -, the antistrophe imagines the god now in the cultic centre of Delphi where Apollo is closely associated with Dionysus, ${ }^{78}$ situated in the middle of the East-West axis between Southern Italy and Thebes, and on Mt. Nysa. The focus now shifts to seeing (ör $\omega \pi \varepsilon$ 1127), what the audience does in the theatre, the place where people watch (derived from $\theta \varepsilon \tilde{\alpha} \sigma \theta \alpha \mathrm{l})$. Besides clear acoustic effects, the spectacle of a procession also has a visual base. But here it is not the people that observe the imaginary arrival of the god, but the flashing smoke-flame of his torches. They are lit with his fire and shine through the night on the twin peaks on Mt. Parnassus, where Corycian

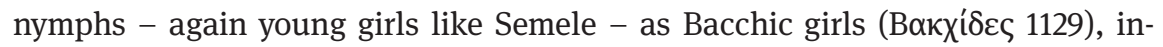
spired by Dionysus, form his chorus with dancing steps. Next to the fire, the water, the spring of Castalia, sees the god (1126-1130). The sublime object of the gaze is the "you" (1126) separated from the agalma. Fire and water stand in parallel order to the strophe: the "you" in the first position repeated (1131) in the second period of the first antistrophe (1131-1136), with strong emphasis laid on the personal touch of the god. The strophic pair culminates in a projection of the celebratory arrival of the god: the Bacchic space, also full of the god,

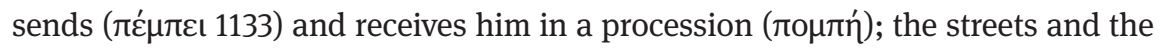
masses are perceived as a sort of second imaginary audience and imaginary chorus in Thebes, while Dionysus is the choral leader of arriving and welcoming masses that fuse at the goal of the trajectory. He is also the one who observes

must not die. At the last moment even Antigone, facing death, seems to wish to step back from her decision. Yet she still desires death, and through the mystic allusions the chorus evokes hopes for a happy afterlife; see also Henrichs 1990, 266-267.

78 See Bierl 1991, 91-94. 
and oversees this spectacle of his own homecoming. Thus, despite entering from outside, he has a view over the inner space of the city, the crowded streets. ${ }^{79}$ The

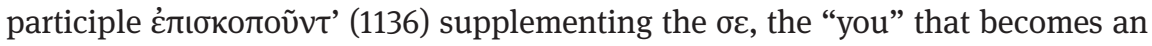
object receiving an action derived from natural places, is taken up in the address

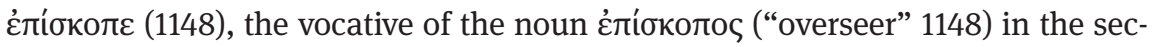
ond antistrophe.

In an extended warm-up, possible routes of arrival are imagined, opening a huge Greek space of Dionysian cult. As pointed out, one route extends from far to the West, from Southern Italy, renowned for its mystery cults, via Eleusis, the location of Greece's most famous site for mystery initiation, closely linked to the cult of Athens, to Thebes, his dangerous birthplace caught in incest and circularity, the stage of tragic events. During this procession via Eleusis, Attica in the here and now, the Attic nature of the chorus, comes into the fore as well, culminating in the very last word, his Eleusinian appearance as Iacchus (1152). Moreover, the Eleusinian cult is an alternative - all Attic citizens are initiated - that focuses particularly on the Dionysian dimensions of death and afterlife. ${ }^{80}$

The origin of the second possible advent route is the Panhellenic cultic centre of Delphi where Dionysus shares the cult with Apollo, both gods complementing each other. ${ }^{81}$ Like in Thebes terrible mythic deaths also took place in Delphi and the Thyiads celebrate wild performative rituals on Mt. Parnassus, comparable to those on Mt. Cithaeron near Thebes. ${ }^{82}$ Or Dionysus might arrive from the North or the East, from Mt. Nysa, located in more than a dozen places, but here, probably, Thrace is meant, as in Iliad $6.133 .^{83}$ Or it is the Nysa of Euboea renowned for its green vegetation ${ }^{84}$ - the scholiast to line 1133 associated the green akta with the woods in Euboea or still with Mt. Parnassus. Be that as it

79 On the streets as processional way for the arrival of the "coming god" in the city, see Eur. $H F$ 783; Bacch. 86-87; Philodamus Paean, lines 144-146.

80 On Soph. Ant. 1146-1152, see Henrichs 1994/1995, 77-78; Bierl 2011a, 323-324; Ford 2011, 345, 347-348.

81 On the interdependence and overlap of both gods in Delphi, see the Paean of Philodamus and Cullyer 2005, 6 (with literature).

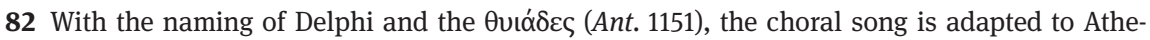
nian cultic ideas, i.e. the Panhellenic worship of Dionysus in Delphi has a specific cultic connection with Athens. Pausanias (10.4.2-3) reports that the Athenians sent their own Oíaбos of $\theta v i \alpha ́ \delta \varepsilon \varsigma$ to the mountains above Delphi, where they performed their nightly celebrations together with the Delphic maenads on the heights of Parnassus near the Corycian Cave, the scenery also described in lines 1126-1130; see also Henrichs 1978, 136-137, 152-155.

83 See also Cullyer 2005, 4, 8-18; the scholion ad Soph. Ant. 1131 associates it with Phocis to keep it consistent with Mt. Parnassus.

84 This is the opinion of most commentators. 
may, the movement is now not only horizontal, but vertical, down from the mountains, the place of the oreibasiai, toward the city on the plain. A thriving, idyllic landscape sends the god down, sends him home to Thebes, the "coming god", who tends to manifest himself, so that he might still help in the very last moment.

The venues consist of idyllic bays, springs and rivers; the hills of Mt. Nysa are "rich of ivy", the shore is "green" and "rich of vine" (1131-1133). All these attributes project the Dionysian energy of vegetation, which becomes manifest with the brimming growth of vine and ivy, the toxic substances of mania. ${ }^{85}$ The futility of this hope for salvation and cure in the very last moment, is captured by the adjective "lamenting", specifying the gulf (1145), anticipating imminent catastrophe. In the Bacchic chronotope, nature becomes active, sees, sends and ejects voices. Dionysian ecstasy and pathos is somehow transferred to the Greek landscape that in a kind of projection, or "pathetic fallacy", assumes Dionysian traits and agency. ${ }^{86}$

Moreover, many features of the Bacchic chora are echoed in the second stasimon. ${ }^{87}$ Also in this song that thematizes hyperbasia (605), transgression, desire and ate (583, 614, 624, 625), "that inescapable complex of delusion, error, crime, and ruin", ${ }^{88}$ water, waves $(588)$, shores $(591,592),{ }^{89}$ lamenting landscape connected with the sea (592), ${ }^{90}$ light (610) and fire (619) ${ }^{91}$ are prominent. "A certain god" (597), one "from the lower deities" (601-602), an anonymous god (624), must be identified as Dionysus, the hidden mastermind in the background (cf. also 278-279). Despite functioning as Lysios, he will not come to bring salvation

85 On wine and ivy that in cult and myth represent regular cultic attribute of Dionysus, see Blech 1982, 183-201.

86 After Henrichs 1996b, 61 n. 49, I apply this term coined by Copley 1937 from bucolic poetry to this remarkable phenomenon of poetic, pathetic symbiosis with the natural environment in $\mathrm{An}$ tigone. See also Eur. HF 782-784, where "the polished streets (óyviaí) of the seven-gated

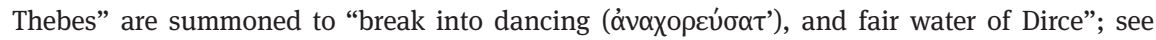
also Eur. Bacch. 114, where in the Dionysiac atmosphere "the whole land will dance at once" ( $\alpha \dot{v}$ -

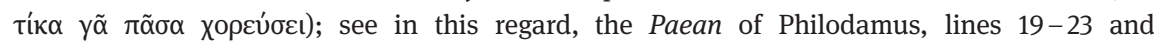
Bacch. 726-727, where "the whole mountain with its beasts participates in the Bacchic dance, and everything was set in rapid motion”.

87 Usually the resonances with the parodos are stressed; see e.g. Oudemans and Lardinois 1987, 154-159; Rhodighiero 2012, 162-164; on the resonances with the second stasimon, see Cullyer 2005. On the Dionysian recurrences and network in the entire Antigone, see below and Cullyer 2005; Bierl 1989.

88 Griffith 1999, 219.

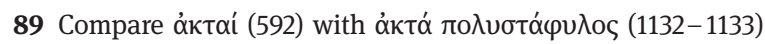

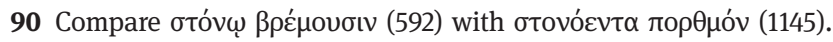

91 Compare Ant. 1126-1127, 1146. 
or positive catharsis (cf. 1143); a family just like Oedipus' Theban clan caught in

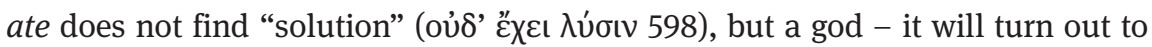
be Dionysus - tears it down (597-598), dissolving everything. In the second stasimon, the chorus sings about destruction due to ate and transgression. The images of wind,,$^{92}$ earthquakes (583), ${ }^{93}$ shores and waves are just metaphors to emphasize catastrophe in the familial realm. The song displays again a chora where Dionysus and the tragic disaster become real. In the fifth stasimon Dionysus is summoned to wander through it and become epiphanic. In passing through the chora he takes on shape and will do exactly what the chorus sang in the sec-

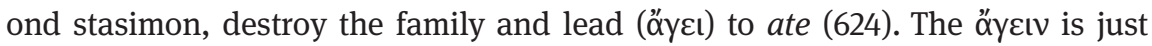
what the chorus leader, the xopayós, does. He will lead his entourage and bring ate, delusion, error, chaos, crime and total ruin. Leading the chorus through the chora in a procession, he becomes manifest as a tragic god, in a cyclic dance that includes the forces of the cosmos, he causes death and destruc-

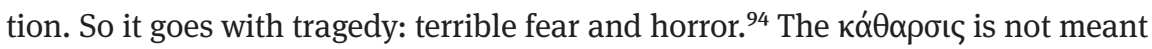
for the dramatic figures but - as in Aristotle's famous treatment in his Poetics - for the audience, cleansed from these emotions by watching and empathizing with the terrible events. ${ }^{95}$

If Dionysus takes the route of death and mystery from Italy to Eleusis, he must pass the Corinthian and perhaps even the Saronic gulf - the scholiast mentions even the Sicilian gulf regarding line 1145 - that would both moan and thus eject sound patterns at the prospect of coming events, consequences of the god's arrival in Thebes. But if Euboea is meant in the idyllic description of lines 1131 to

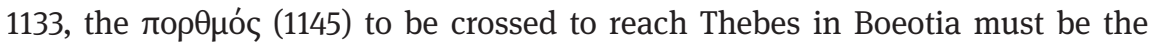
Euripus Strait, the narrow channel of water separating the green island from the mainland. ${ }^{96}$ And if the chorus imagines Mt. Nysa to be in Thrace, it would be one big north-western route through the Aegean sea, over Euboea to Thebes. ${ }^{97}$ From Thebes the god had to traverse the wild Mt. Cithaeron to reach the Attic border in Eleutherae. From there Dionysus Eleuthereus arrived annually as a

92 On the motif of wind, see Cullyer 2005.

93 Compare with Ant. 153-154, 1273-1274.

94 On the "ironic" or metaphorical epiphany of a violent Dionysus, see Winnington-Ingram 1980, 115; Bierl 1989, 53; Bierl 1991, 130 -131; Bierl 2011a, 322-325; Cullyer 2005, 18 -20.

95 Macedo 2011, 407, therefore relates the purifying aspect to Dionysus' role as Lysios in mystery context.

96 See the scholiast ad Ant. 1145; as an alternative he gives the Sicilian sea, attempting to es-

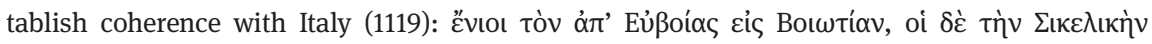
$\theta \alpha \dot{\lambda} \lambda \alpha \sigma \sigma \alpha v$.

97 For this possibility pleads Cullyer 2005. 
statue (agalma) to the Athenian theatre in a preliminary procession preceding the dramatic competitions at the City Dionysia. The exact way is unknown but Eleusis was situated on one of the main roads. Devotees, nature and the god, myth and cult, darkness and light, internal and external spaces, Thebes as tragic venue and Athens as the place of the actual performance, they all fuse into a synaesthetic performance of choreia and pompe. This impression of totality is enhanced by the chaotic accumulation of places, the zig-zag alternation of Thebes, the place of the tragic plot, and other places abroad, focusing on the Apollonian Delphi and ending with the Attic Eleusis. ${ }^{98}$ As Rohdich points out, "centrifugal movement" alternates with a "centripetal" one. ${ }^{99}$ This feature augments the interplay between the left and right hemispheres of the brain and between ergotropic and trophotropic exchange. The fact that everyday inanimate objects assume their own agency and vitality in the Bacchic chronotope of chorality enhances the impression of fusion and totality. Strangely enough, and against our expectations, it is not the deity animating things through ecstasy. Rather within the chora painted in this choral ode, the god stands in the accusative, the affected object, things like the flashing smoke-flame and water act as subjects instead. They see Dionysus. In the same way that shores send him on a procession or words cry euoi and render him ecstatic. The Bacchic chora and the chorality act as catalysts. In this receptacle, energy is vitalized and transformed into an active force otherwise inherent in the object only as latent and passive potential.

The second strophe emphasizes that Dionysus holds Thebes in the greatest honour of all cities, as it is the inner space from where he watches the arrival of his own agalma in a wild and choral procession. And he shares this function with his "lightning-struck mother" Semele (1137-1139). Lines 1115-1117a already anticipated this passage. The Dionysiac chora par excellence is female, the fate of his mother again underlined. Semele suffers a death by lightning, yet it is Dionysus who crosses the border to fire and lightning, bringing about the fatal end. Semele's death happened in the mythical past. Since he is related to purifying fire in the past, he should come also now (vṽ $\delta^{\prime}$ 1140). This is the decisive appeal, the preces of the cletic song delayed until this very late point - all the previous utterances, the initial invocatio and the naming of the possible abodes

98 Thebes 1115-1118a / Italy 1118b-1119a / Eleusis 1119b-1121a / Thebes 1121b-1125 / Delphi 11261130 / Nysa 1131-1133 / Thebes 1134-1136 // Thebes 1137-1145 / Delphi 1143, 1150 - 1151 / Eleusis 1146-1152. Macedo 2011, 407-408 detects a chiastic order: A 1126-1133 (Delphi and Euboea); B 1134-1136 (Thebes); B 1137-1142 (Thebes); A 1143-1145 (Delphi and Euboea).

99 Rohdich 1980, 210. 
whence he might arrive, functioning as a surrogate of the pars epica, aligned in a long chain of signifiers closing the gap to the Other.

The chorus calls upon Dionysus to have an epiphany, coming and dancing

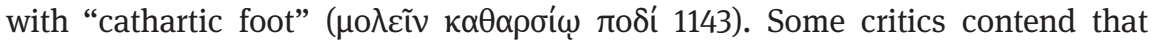
the plea for purification would not be "tailored specifically to Dionysus" and argue that Apollo as purifier would be chief among those summoned. That Dionysus figures at all in Apollo's presence stems from the fact of Thebes' being his birthplace. ${ }^{100}$ Other scholars offer a better solution, pointing out that Dionysian ritual strove for cathartic effect through the music of flutes and ecstatic dancing. ${ }^{101}$ If, in his analysis of the genre, Aristotle correctly asserted that tragedy evoked a catharsis in the viewer (Poetics 1449b.24-46), then, in a tragedy performed in honour of Dionysus, an invocation of Dionysus as purifying god logically follows. The request is fulfilled, however, differently than the chorus expects. Ultimately, the end of Antigone represents purification in its fullest sense: Antigone becomes, as it were, a sacrifice to Dionysus, the source of her divine inspiration, cleansed of her offense against the polis and miraculously uplifted. Creon's "purification", on the other hand, comes with the deaths of his son and wife, payment for his hubris against the god, because, like Agaue in the Bacchae (1296, 1374-1376), his insight into the god's great epiphany comes too late.

Thus, the appeal is a most metatragic affair. Just as the entire Theban population desires purification from a violent disease, so the Athenian people in the theatre need from the sickening violence. This expression of vóoos recalls Teiresias' account in lines 1015-1018. It is, however, less the pollution caused by Polyneices' unburied corpse than the inner strife, stasis, in the city of Thebes, as analyzed by Haemon earlier. ${ }^{102}$ Healing can be accomplished by wild exorcist dances conducted in homeopathic manner, like in the Corybantic cult. It has been shown by Scullion and others that Dionysus is envisaged as a dancer, with emphasis on his foot serving as a pars pro toto for choral dance. The пой epitomizes the kinetic movement of the entire body. ${ }^{103}$ It can serve also

100 E.g. Förs 1964, 82 and Rohdich 1980, 210, 214, who sees Dionysus just in his positive, almost Apollonian, aspect as polis-god.

101 Vicaire 1968, 363-364 and n. 39 and Scullion 1998. Similarly also, even earlier, Eitrem 1915, 92-93 and Moulinier 1952, 116.

102 See Scullion 1998.

103 See Scullion 1998, 101-104 and Bierl 2001, 83 (Engl. 2009, 64), esp. on the mention of the foot as choral self-reference; e. g. Alcm. fr. 1.48, 78; fr. 3.10, 70; Pind. fr. 52f.18; Aesch. Eum. 371, 374; Eur. HF 978; Heracl. 783; Tro. 151, 325, 333-334, 546; Bacch. 864, 1230; Ar. Thesm. 659, 954, 
as an instrument of aggression when someone steps upon one's victim, jumping on the body. The infinitive as imperative is very forceful. But the $\mu$ o $\lambda \varepsilon \tilde{v} v$ (1143) also underlines the movement of procession, the coming as arrival. The choral image directly glides into the second antistrophe entirely occupied with dance.

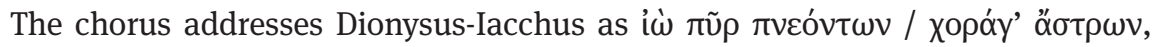

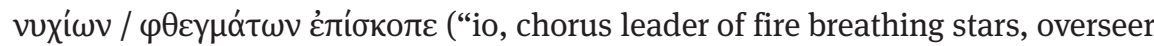
of nocturnal cries" $1146-1148){ }^{104}$ The choral god is called to appear as chorus leader of the actual chorus as well as the chorus of the initiates' procession in Eleusis and the maenadic-mystic chorus of Delphi projected simultaneously onto the chorus of stars. He should appear as supervisor of the nocturnal voices, particularly of the Iacchus-shouts that his ecstatic group of Thyiads in Delphi or the initiates in Eleusis emit. The chorus references itself through song, voice and dance, leading to a rapid succession of different choral formations that culminate in the cosmic chora where the stars and gods form choruses. Like in those Russian nesting dolls, one chorus builds upon the next in concentric circles: The chorus of the stars the outermost ring, beneath which dance the Delphic Thyiads, then the Eleusinian initiates and, in the innermost circle, so to speak, the Athenian chorus of the actual performance. Their projected leader on all levels is Dionysus. ${ }^{105}$ Since the Attic perspective of the audience is always included in the open chora of chorality, they call upon Iacchus, the dispenser

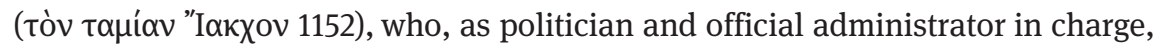
becomes the leading figure of the violent movement to cleanse the sickness affecting the entire population, the demos, in the tragic city of Thebes. The god gives everyone his share. While the song is performed Antigone transgresses the boundary to the netherworld, to Polyneices and to Hades-Dionysus. Both Creon and the voice of the polis hope in vain. Somehow the choreuts sing themselves into a Dionysian delusion. But Dionysus' catharsis in tragedy will have a tragic result. The god is magically drawn in, he does not, contrary to the excessive expectations of the chorus, have an actual epiphany, but will be manifest as the hidden agent bringing destruction to Creon's house and the end of tragedy. As a god - according to the generic laws of tragedy - he will, of course, not appear on stage, but does so in metaphorical and theatrical terms.

The women, in their madness ( $\mu$ เvó $\mu \varepsilon v \alpha \mathrm{s})$ and their shouting of iakch-cries

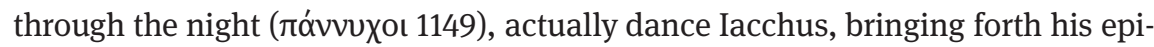

969; 981-982, 985; Lys. 1306, 1309, 1317; Ran. 331; Eccl. 483; Autocrates fr. 1.1-6 K.-A.; Pratinas PMG 708.14; PMG 939.6 (Ps. Arion); Timoth. Pers., PMG 791.200.

104 Dionysus is often notionally envisaged as a virtual divine choregos or exarchos; Bierl 2001, 42, 144 n. 101, 145, 147-148 (Engl. 2009, 29, 120 n. 101, 122-124).

105 Henrichs 1994/1995, 78 speaks of a "cascade of choral projection". 


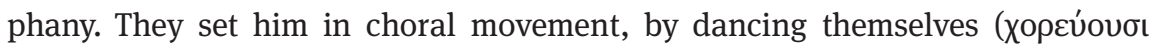
1152). The diction is again unusual. It is not Dionysus who dances, expressed in the middle voice $\chi о \rho \varepsilon u ́ \varepsilon \sigma \theta \alpha$, rather others, his entourage of wild women, who, full of the god, transfer their frantic energy and set the god, the actual source of power, in motion at last, bringing about his arrival in purely cosmic, star-like energy. ${ }^{106}$ It is again the chora which transforms the god so that he activates his energy. In the last antistrophe we witness the perspective of the Eleusinian procession culminating in the circular dance at the Callichoron Well, the "Well of the Beautiful Dance", also called Parthenion, the "Well of the Maidens", present to the audience in the orchestra, ${ }^{107}$ but again fused with the Delphic Thyiads (1151). This kyklios choros evoked also starry dances in the sky, etherial choreia of mystic light. ${ }^{108}$ Night and day intermingle, the song ends in a projected pannychis, where Iacchus should appear like fire in the night, to shine, to cure and to kill as well. The transgression to the burning fire already alluded to in lines 1115 and 1139 culminates in the last antistrophe. The destruction might assume a cosmic dimension, while the assault of the Seven with Polyneices' assistance has already been associated with the element of fire $(136,200,286)$.

We find a very similar description of the Eleusinian mystic dance in self-referential terms in the parodos of Aristophanes' Frogs. In the complementary genre of comedy, Iacchus is again called in a hymnos kletikos as the chorus leader. The personification of the ecstatic inarticulate shout of iterated syllables "I $\alpha$ k’ $\tilde{\omega}$ "I $\alpha \kappa \chi \varepsilon$ / "I $\alpha \kappa \chi$ ' $\tilde{\omega}$ "I $\alpha \kappa \chi \varepsilon$ (316-317, cf. 323-325) is invoked as the "deviser of

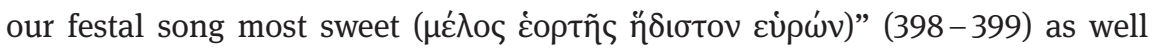
as the "lover of the dance" $(402,413)$ who is to lead the mystic dancers in a procession - also an allusion of course to the renowned Eleusinian procession onto the dramatic scene of the mystic underworld meadow and the orchestra

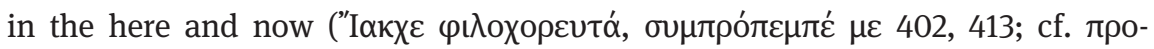
$\beta \alpha ́ \delta \eta v$ है $\xi \alpha y$ ' 351). Just like in the climax of the fifth stasimon of Sophocles' Anti-

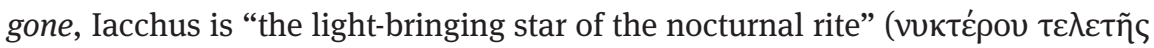

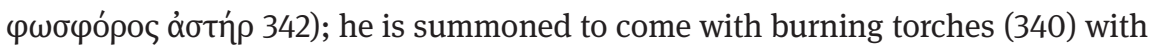
which to light the meadow in Hades (343) where vegetation sprouts. His epiphany consists again of light and fire. Again we have the same progression from

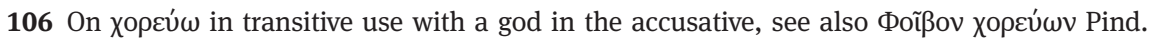
Isth. 1.7; see Henrichs 1996c, 46-47 with n. 59 and Furley and Bremer 2001 II, 278-279 ad 1151-1152 (mentioning an obiectum affectum and even effectum). See also Eur. Ion 10841086 (in the medium); Rodighiero 2012, 154 n. 61; on the meaning of 'to set dancing', see Eur.

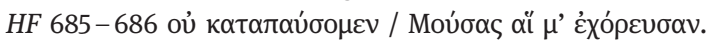

107 See also Eur. Ion 1074-1086.

108 See Csapo 2008, esp. 267-272. 
linear march to circular dance, from the horizontal to the vertical axis (in the Underworld and in the sky). In a similar concentric chorality he is envisaged as leader of a projected astral chorus guiding "the youth that makes the chorus"

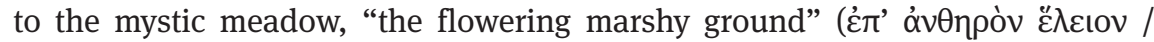

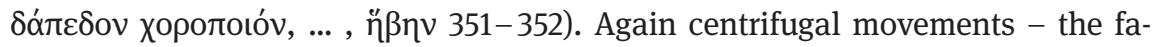
mous procession in the month of Boedromion went from Athens to Eleusis overlap with centripetal ones. As a matter of fact, Iacchus is again envisaged as coming through the chora in a procession, through the famous marshland where the sacred marriage of Dionysus with the Basilinna takes place in the night of the second day of the Anthesteria. In the passage through this receptacle the epiphanic energy of the god materializes again.

Coming back to the fifth stasimon of Antigone, the axis of space, the Dionysian chora is transferred from the mysteries in Italy and Eleusis to Greece's marvelous landscape, to Eleusis and a mystic dimension of sky-dance. This celestial climax merges Bacchic-Orphic, Pythagorean and Eleusinian perspectives of a fully orchestrated cosmos, a choreia of heavenly spheres, stars, gods and men, all united in an eternal, circular movement. The initiates reflect this mystic vision on the gold lamellae. On the leaf of Petelia, dated around 350 BC (476 Bernabé = 2 Graf and Johnston, lines 6-7), an initiate claims: "I am a child of Earth and starry Sky, / but my race is heavenly". ${ }^{109}$ On a leaf found in Thurii, a Panhellenic colony rebuilt with Pericles' help in $443 \mathrm{BC}$, just one year before the performance of Antigone, an initiate argues (488 Bernabé = 5 Graf and Johnston, lines 4a-6): "But Moira overcame me and the other immortal gods / and the star-flinger with

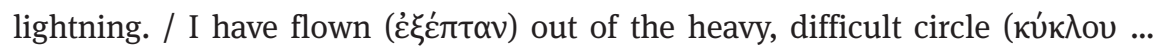

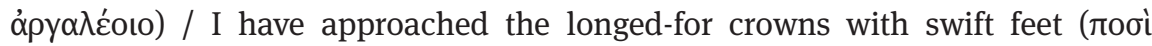

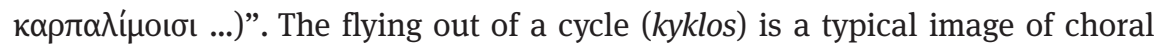
dance, indicating the moment when the chorus is left in the sky - the liberation came about through typical Bacchic lightning. Moreover, the movement with "swift feet" toward the garland (stephanos) is another metaphor for circular movement, obviously now taking place in the Underworld. ${ }^{110}$

109 See also the leaf of Thessaly 484 Bernabé $=29$ Graf and Johnston, lines 3-4 and the lamella from Pharsalus 477 Bernabé = 25 Graf and Johnston, lines 8-9 (where the second part is changed to "my name is 'Starry' [Asterios]"). Regarding the first part, see the leaves from Rethymnon 484a Bernabé = 18 Graf and Johnston, line 3, from Mylopotamos 481 Bernabé $=16$ Graf and Johnston, line 3, from Eleutherna 478, 479, 480, 482, 483 Bernabé = 10, 11, 12, 13, 14 Graf and Johnston, line 3 and from Hipponion 474 Bernabé = 1 Graf and Johnston, line 10. 110 See also Csapo 2008, 270 - 271. For foot as synecdoche for dance, see above n. 103. For flying and gliding, see Henrichs 1994/1995, 106 n. 105; Bierl 2001, 49 and 297 n. 512 (Engl. 2009, 34 and 263 n. 512). A red-figure astralagos vase by the Sotades painter (British Museum E 804, 460 - 
On the axis of time, past and present perspectives merge: since Thebes is his place of birth, where, in the past, tragedy befell Semele, Dionysus honours his city most of all (1137-1139) in the present, and should come "also now" (1040), in anticipation of the future. In terms of space, the Dionysian song proves particularly complex, reaching from the Attic soil of the here and now to a wider Greek cultic space and further to a cosmic space that encompasses the perspective of mystery and death and then even to the city of Thebes of the there and then of the plot reenacted as the here and now through mimesis. The ritual chorus accompanies and enhances the movements of the projected dances of other maenads who drive the god of mania mad and convey the energy that leads to death and violence. Ritual festivity collapses into mythic violence; hope and purification into lament and catharsis through pathos. Dionysus oscillates between Hades, Thebes, Delphi, Eleusis, Athens and the nocturnal sky. He breathes fire like the wild dragons of Thebes, bringing light and destruction into the nocturnal darkness of the cave, in which Antigone is imprisoned, and into Thebes. Through wild cries and dancing movements he is magically called to appear. He should become epiphanic through his healing foot - the emblem of the arriving god - and dance. Procession and dance are the theatrical modes through which the god manifests himself. The musical performativity reenacted in mimesis overlaps with the real one in the orchestra. He oscillates between all perspectives of time and space, past, present and future, absence and presence, happy festivity and grisly lament, here and there, life and death. The wild performance of the choral song symbolically helps enhance the peripeteia and metabole from hope to destruction, from life to tragic death. The numerous effects of presence help turn this epiphanic song into a dramatic climax, ${ }^{111}$ emblematic, in a way, of the Bacchic-choral chronotope: we have seen that time and space have special blurring effects; everything is hybrid and the song gives the impression of presence, fusion and aesthetic totality.

\section{The Dionysian Chronotope in the Remaining Play}

In the end I wish to show that the fifth stasimon is not exceptional in Antigone, rather the culmination of a pattern. As I have argued elsewhere, Dionysus is the decisive reference and hidden agent in Antigone. ${ }^{112}$ In the following I want to ex-

$450 \mathrm{BCE})$, depicts three groups of women from a female chorus who seem to fly. On the garland metaphor, see Caspo 1999/2000, 422.

111 See Beil 2007, 162-168.

112 Bierl 1989; Bierl 1991, 62-67, 127-132. See also Zeitlin 1993, 154-161. 
plore in what way Antigone is linked with Dionysus and his chora, whereas Creon serves as the opposite. In Thebes, the place of the total Other, as Froma Zeitlin put it, ${ }^{113}$ Oedipus' sons, Eteocles and Polyneices, could not share power; they fell into conflict and ultimately slew each other in the famous battle of the Seven Against Thebes. Creon, the new ruler, now tries to take advantage of this situation, emphasizing solidarity by framing it within polis ideology. As his first official act, he issues a decree according every honour to Eteocles, who fought for the polis, but refuses burial for Polyneices, who took up arms against his homeland (192-206).

The Dionysian captures the ambivalent stance toward one's own city as the chorus, in the parodos, exalts the victory over the terrible foe at dawn of the next day. In theological categories it paints a vivid picture of how Thebes, with the assistance of Zeus, the incarnation of righteousness, has beaten back the attackers. In the joy of victory the chorus calls upon its fellow citizens to stage nightlong victory celebrations for all the polis deities with Dionysus leading the victory train. With this the members of the chorus affirm this god's power in making us forget previous horrors through the intoxicating ecstasy of dance and music $(150-154) .^{114}$

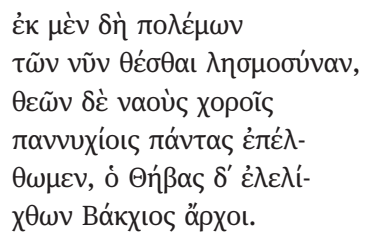

After the recent wars create for ourselves forgetfulness, and let us approach all the temples of the gods with night-long choral performances, and let him who shakes up Thebes, Bacchus, lead our dancing!

The god of the play, embodying, in this song, festive joy and political solidarity for the whole city, replicates the Athenian Dionysus of the present performance. Yet in this passage he proves ambivalent towards Thebes, too. The shaking of the ground in night-long choric dance can also be understood to anticipate the total destruction that ensues; the cosmic and elemental star-dance in a pannychis as presented in the fifth stasimon. The Dionysian that manifests itself in fire storms

113 Zeitlin 1990 and Zeitlin 1993. On Dionysus in tragedy from Thebes to Athens, see also Bierl 1991, 45-110. On this spatial tension in Antigone, see also Zeitlin 1993, 154-161.

114 Consigning sorrow to oblivion constitutes a standard part of Dionysus' positive effects on his human worshippers; Eur. Bacch. 188-189 and 282-283. 
will ruin and reduce the polis to rubble like an earthquake - in similarly miraculous ways the god becomes epiphanic in the miracle of the palace collapsing in the Bacchae (576-603, especially 585-593, and 605-606) -, while the god of tragedy again leads the chorus. Tragedy expresses its own tragic logic in choral and musical terms. Its god is indeed the chorus leader who leads the figures to ate (624), and to some extent, to lysis (cf. 598). Moreover, the aggressor Polyneices also evinces a Dionysian interpretation. As the chorus describes it, he as "fire-bearer" (

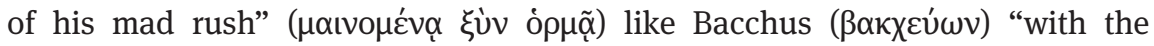
blast of hateful wind" (135-137). ${ }^{115}$ In his ecstatic destructiveness, he becomes the human embodiment of Ares, who in other Greek tragedies also aligns with Dionysus' order-destroying nature. ${ }^{116}$ Yet with regard to the local tutelary deity, the chorus stylizes Polyneices simultaneously as an enemy of both Dionysus and the polis. Polyneices' burial drives his sister Antigone into conflict with Creon. The new leader and uncompromising representative of the polis ideology

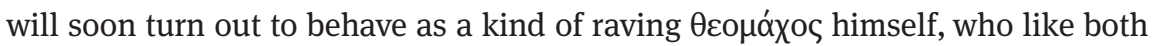
Pentheus in the Bacchae and Lycurgus mentioned in the fourth stasimon of Antigone (955-965) adopts Dionysian characteristics even as he struggles with the god. The fire and the breath in Polyneices' nightly attack, as well as the Bacchic mania led by Dionysus clearly anticipate the second antistrophe of the fifth sta-

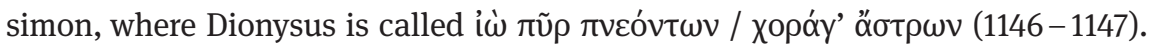
Dionysus is positioned at the border of fire and terrible light, storm and destruction.

Antigone is linked to her brother Polyneices through an almost incestuous love. At the same time, she is the agent of Dionysus himself. Situated at the very border between life and death, she feels a strong desire to trespass it and

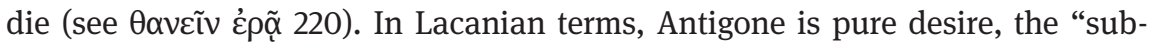
lime object", transcending all social categories in her total enjoyment (jouissance), going beyond the pleasure principle. Eros and her love of the dead brother, the desire to be united with him through death, serve as leitmotifs in Antigone (220, 522-526; philein 781-805). The guardian's description about Antigone's first burial with dust deals with the chora, the edge of the city, and bears all the signs of a miracle ( $\theta \alpha \tilde{u} \mu \alpha 254)$ also typical of Dionysus' epiphanies. The cho-

115 Almost all commentators connect these lines with Capaneus, who at least in the parodos is not explicitly named. As far as I can see, only Segal 1981, 166, 170, 197, 202, Lonnoy 1985, 68 and Zeitlin 1993, 156 connect this Bacchic characterization to Polyneices. I repeat here my argument from Bierl 1989, 47 and Bierl 1991, 63. Capaneus' name can only be derived from the version of the myth handed down from Aeschylus in Seven against Thebes.

116 See Eur. Bacch. 302-304; see Dodds 1960, 109-110. 


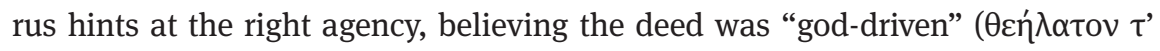
oüpyov 278-279). It is a $\delta \varepsilon เ v o$ v, something powerful and tremendous (323). In the famous first stasimon (332-375) the chorus takes up this theme of the wondrous man, reflecting on the fact that the only real boundary for men is death the boundary Antigone desires to transgress. When Antigone, caught in act, is

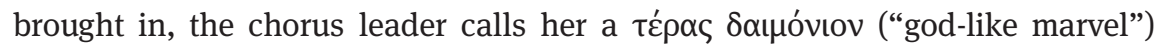
(376). The guardian then triumphantly reports Antigone's second burial and how she was caught (407): It was the dangerous hour of midday beneath the burning Mediterranean sun. "Suddenly a whirlwind lifted from the earth a storm of dust" - a natural wonder again - "a trouble in the sky" (417). Dionysus manifests himself in that wonder (thauma), in fire, heat and wind. The immedi-

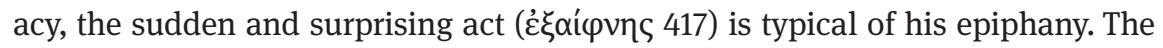
group closed their eyes ( $\mu$ $\sigma \alpha \nu \tau \varepsilon \varsigma$ ), like in a mystery epiphany, before the "divine sickness” ( $\theta \varepsilon i ́ \alpha v$ vóoov 412). Dionysus can either purify or send a plague. In this case it is the little girl Antigone, who "lamented aloud with the sharp cry of a grieving bird" (424-425), fulfilling the basic burial rites again with some dust and libations. Interrogated by Creon, she affirms that she obeyed "the laws

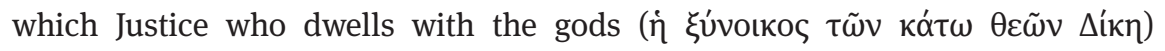
below established among men" (451-452). In her desire for death she says that if she must die before her time, she would count that a gain (461-462).

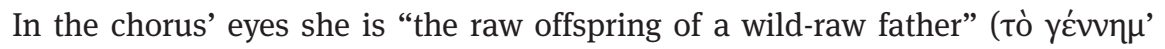

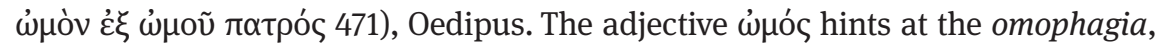
the custom of eating raw flesh among the god's Bacchants. Additionally, Polyneices's body is polluted by raw-eating dogs (697), who like to tear their victim apart. $^{117}$ In Creon's eyes, Antigone is crazy ( $\lambda v \sigma \sigma \tilde{\omega} \sigma \alpha \mathrm{cf}$. 492; see 633; övous 562; $\mu \alpha i ́ v \eta$ 765), recalling Dionysus' lyssa and mania. ${ }^{118}$ Contradicting her sister Ismene, Antigone claims her deed was done in accordance with Hades and the ones below (543), the dead. As already established, Hades is identical, in certain respects, with Dionysus; ${ }^{119}$ thus Antigone acted with his consent. She seeks

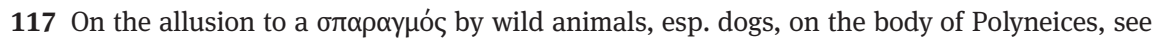

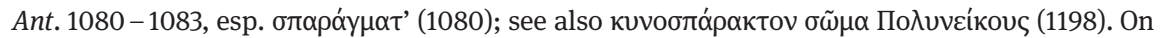

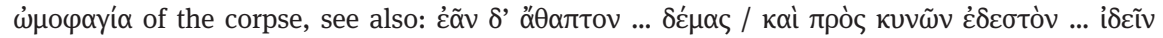

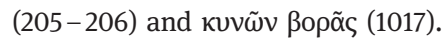

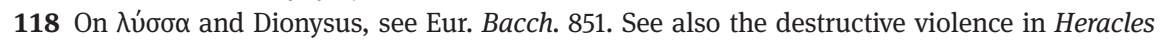
(HF 867-897), where Lyssa, the personification of frenzy, sets Heracles within an ecstatic dance

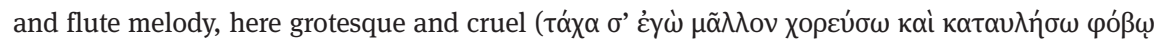
(HF 871; cf. 879); see Bierl 1991, 79-89, esp. 85-87, 140-146.

119 Heraclitus (DK 22 B 15) and above n. 72. 
death now (555, 559): her status is already in-between, her soul long dead ( $\dot{\eta} \delta$ '

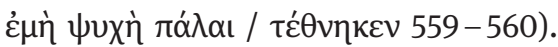

Above we scrutinized the common imagery linking the second stasimon to the fifth. In Haemon's view his father tramples upon the honours of the gods

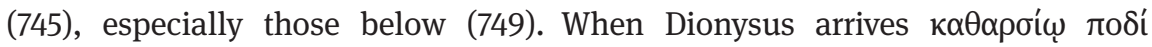
(1143), he takes just revenge. With his feet he tramples, so to speak, Creon in turn, destroying his family. The rocky cave imprisoning Antigone, where she is to starve alive, serves as, what Lacan calls, the boundary to the second death. In Creon's words she should learn there that "it is fruitless labor to revere that which is in Hades" (780). This is ironic since Dionysus will strike back. The third stasimon is a song totally dedicated to Eros, to desire, the emotion that drives Antigone. "The one who has experienced you is driven to madness ( $\mu \varepsilon \dot{\mu} \mu v \varepsilon v)$ " (790), the Dionysian mania. The chorus underlines that "radiant de-

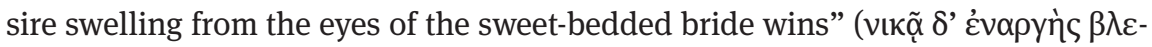

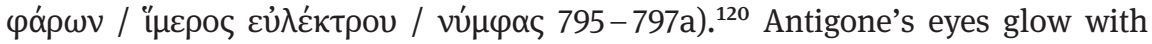
beauty, with a desire that shines. It is the dangerous Dionysian light that will strike back and conquer his enemy. In her long kommos Antigone now embarks on her last journey (897-898) across the boundary to her prison, located at the very brink of real death. Hades-Dionysus leads ('óycı 811) her to the shore, akta, of Acheron (810-812). It is the verb indicating that Dionysus 'leads' the chorus and the individuals to ate. Now, in a way, he becomes the hidden leader of a small procession to the chora, the Dionysian cave where Antigone will transform her power through suicide. Responding to the chorus' praise she compares her-

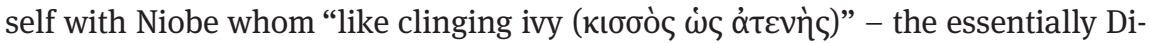
onysian plant - "the sprouting stone subdued" $(826-827){ }^{121}$ The chorus criticiz-

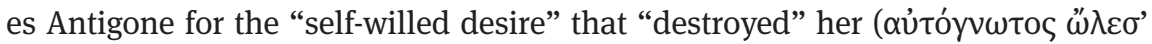
ópyó 875). Bound to Dionysus, the total Other, she views herself now as complete reversal of the usual perspective $(813-816,819,820,847,851-852,867,876-877$, $879,881-882)$. In her so-called calculation (904-915), that many critics, beginning with Goethe, wished to athetize on humanist presumptions, on ethical as well aesthetic predilection of taste, Antigone reaffirms her very special relation to Polyneices (and Dionysus) in a radical stance. ${ }^{122}$

120 For Lacan 1992, 268 this expression means Antigone’s “desire made visible”. See also 281. 121 For Lacan 1992, 268 the myth of Niobe mentioned in Ant. 823-833 represents the decisive "image of limit" around which the "the whole play turns". See also Lacan 1992, 281 and Miller $2007,2$.

122 Its authenticity has been defended in recent scholarship; see now Griffith 1999, 277-279 ad 904-915. For Lacan 1992, 278-279 this scandalous passage is a proof of Antigone's absolute will 
In the fourth stasimon the Dionysian association of the plot comes again to the fore. To console the condemned Antigone, the chorus presents three examples from myth, in which people of significant rank, like the heroine, suffered the terrible fate of being entombed alive. In the first antistrophe (955-965), between the descriptions of Danae (944-954) and Cleopatra (966-987), the chorus mentions the story of Lycurgus, the king of the Edonians, punished because he opposed the introduction of the cult of Dionysus. The chorus therefore speaks an implicit truth for Creon, reporting of Lycurgus that he "tried to check the inspired women and the Bacchic fire, and he angered the Muses who love the flute" ( $\pi \alpha v^{-}$

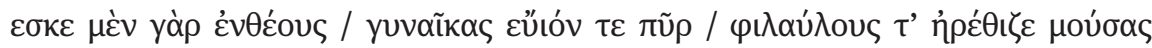
963-965)". ${ }^{123}$ Logically, we must count Antigone among these women as well. Creon, in a way, follows in Lycurgus' footsteps, opposing the god and his female entourage. Fire and the euoi-cries are distinctive features of the god. In the fifth stasimon his star chorus breathes fire (1146-1147). To stop the fire would mean to halt his energy. Bacchants or Muses, just like nymphs, number among his female followers. In many instances they form a dancing chorus accompanied by flute music. This exactly mirrors the chorus of the performance in the Athenian theatre, being a musical institution. We all know that, in tragedy, it is impossible to stop the Dionysian chorus and its music. Antigone is a girl and bride linked to the god. Soon reduced to only womb and body, she is the receptacle for the transformation of Dionysian energy. The parallel myths are situated in the chora of the in-between as well. Danae is just a body ( $\delta \varepsilon$ pas 945), like Semele, that had to endure the light of sky (oúpóviov $\varphi \tilde{\omega} \varsigma$ 944) and to exchange it for darkness. The light is poetically associated with the golden rain that impregnat-

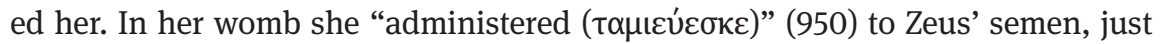
as Iacchus-Dionysus later is called as the tamias, the master to give a share of fate. Just as the chora of the chorus processes energy, Danae's womb serves as the receptacle whence a new hero, Perseus, is born.

While the fifth stasimon is being performed, Antigone takes her very last journey, committing suicide. Her prison has repeatedly been seen as a bridal

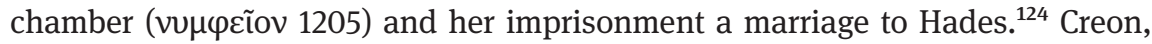
the late-comer, notices Haemon's wailing voice, opens the cave and sees a highly erotic scenario: Antigone "hanging by the neck, fastened by a halter of fine linen

of transgression that manifests itself in the pure language as signification. See also ibid. 254256.

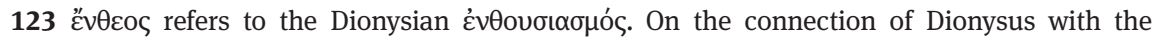
Muses, see Aeschylus TrGF 3.60; Eur. Bacch. 410-411, 563. See also Solon fr. 26 West and Plato Laws 653d.

124 Seaford 1987, esp. 107-108. 
threads, while he was embracing her with arms thrown around her waist" (1220 1223). Failing to kill his father, he commits suicide himself, driving his sword in his side. His end metaphorically resembles impregnation with blood, "he clasped the maiden in his faint embrace, and, as he gasped, he shot onto her pale

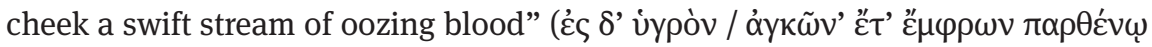

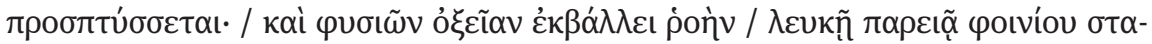

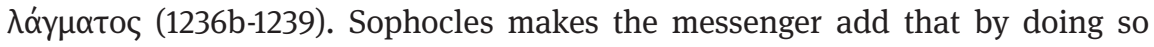

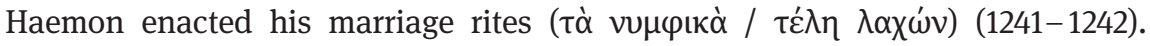
Hanging underlines her virginity. ${ }^{125}$ Nevertheless, she has become a bride impregnated, a receptacle and womb. The hanging girl recalls Erigone, Icarius' daughter. ${ }^{126}$ The Athenian welcomed Dionysus as his guest and gave him his daughter in marriage (Ovid Metamorphoses 6.125). Dionysus repays the hospitality by introducing wine to Attica. The god instructed his host Icarius on how to grow vine and to make it known. Icarius distributed it further to his shepherds. Completely drunk they killed him, thinking he had poisoned them. His daughter went in search of his father and finally found his body. She hanged herself over his grave. Dionysus sent an epidemic suicide wave among virgins that ended only after the institution of the swing-festival. In the ritual, the myth was transferred to the Aiora, the swinging of young girls and virgins on a swing, celebrated on the last day of the Anthesteria, the Chytroi. ${ }^{127}$ In this Sophoclean tableau, Antigone becomes the emblem of a mystic union with Dionysus, with Haemon, the man of blood, as surrogate through whose Dionysiac transformation bitter revenge ensues. According to Burkert, Erigone is to be associated with the Basilinna, ${ }^{128}$ the queen of the city given to Dionysus after the "pollutions" of the "de-

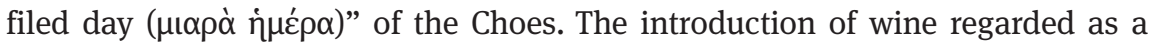
bloody sacrifice is expiated by a night celebration of a hieros gamos. Located in another place of chora, in the Marshes, the "unspeakable", mystic sexual coupling took place in a subterranean oikos, ${ }^{129}$ recalling Antigone's cave. Only vaguely associated with the Athenian Dionysian, the tableau displays the pattern of a pollution to be cleansed. In tragic logic, blood invokes revenge through further bloodshed. Dionysus arrives through the chora, is revitalized through dance and mystic union, which symbolically alluded to sexuality and the triumph of the unspeakable in a mystic beauty. In passing through night, through the sub-

125 Loraux 1987, 7-17, 31-32, 38.

126 See also Borgeaud 2005.

127 Burkert 1983, 241-243.

128 Burkert 1983, 243.

129 See Burkert 1983, 234 n. 16. 
terranean cave, through Eleusinian mystic dance, ${ }^{130}$ with the chora as female receptacle and helper, Dionysus is revitalized and readied to strike back.

\section{Conclusion}

With the help of modern theory this contribution tried to pin down a new structural interplay of time and space in Greek literature. The Bakhtinian chronotope, Lacanian theory, and Kristeva's chora, along with concepts from Jacques Derrida and others, combined with research into choreia, Dionysus, rituality, metatheatre, performativity and, last not least, philological and literary close-reading, all aided in determining a specific Bacchic chronotope in archaic and classical choral song culture. It is deeply rooted in chorality and choric culture. Moreover, this space and time configuration involves Plato's famous chora, the third way, a receptacle in which and from which products of mimesis, mimemata, become vital and take on their vivid energy. Dionysus as the total Other, the unconscious, the god of the middle-ground, of mediation and transformation, serves, in a way, as the emblem of this chor(a)ic constellation. Despite his masculinity, he also has particular links to the female principle. In the poetically achieved Bacchic chronotope, the typical Dionysiac surroundings and atmosphere facilitate his coming into being. From absence, he transforms into pure presence and exuberant energy, expressing himself in epiphany. From chora emerges choros, his special medium of vitality in performativity. In Bacchic choreia we witness little narration, the chorus mostly occupied with its own doings. As in chora these songs are highly poetic yet semiotic, not symbolic, connected to the unconscious, and the Other, whose perception takes place in a dream-like manner. Because of the lack of symbolic signification, Dionysus remains enigmatic, notoriously elusive and meeting with resistance. Those who do understand the ecstatic expressions can abandon themselves and merge via worship with the god. The god of presence and epiphany can manifest himself only through his wild sign production. This is true, in particular, for drama based on multimodal performance of words, music and choral dance, where Dionysus is sometimes summoned to have his epiphany through roaring noise, shrill music by auloi, violent rhythms and excited dance. We witness a strange whirl of reciprocal interaction between

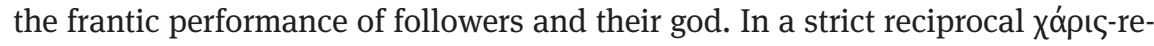

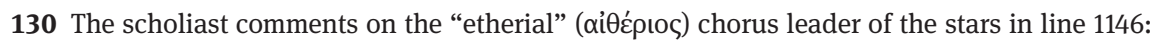

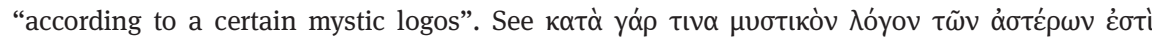
хорпүós. 
lation, ${ }^{131}$ his chorus attempts to please and seduce Dionysus through performative behaviour suited to him while he takes pleasure in the chorus' activity. Often he is called on to take over as notional choregos, thus driving them even madder. Just as they set him in raging choral motion, so too he does with them.

Furthermore, we encounter a strange tendency to project the totalizing feeling onto other mythical choral groups or even onto the cosmos, the stars, onto the entire environment. Under his influence everything fuses: the entirety of nature is envisaged in frenzied motion, the sky, the stars, the earth and the land. He stands in the middle, the surrounding objects revolving around him in a circular dance. In the end, Dionysus is nothing more than the underlying substance, the abstraction of ecstatic, inarticulate signs lacking proposition, signs that crystallize to strange names and epikleseis of the god responsible for that extraordinary experience. As a hypostasized expression of ecstatic performance, Dionysus is present for the insider, the initiates - thus his association with mysteries -, whereas for the outsider it is purely insane behaviour absent any aesthetic meaning.

The Bacchic chronotope is permeable, hybrid, fluid and shifting. Moreover, his chora is a space of arrival in procession where the god transgresses boundaries in sudden epiphany. He manifests himself in multimodal ways in performance, and his energetic vitality, oscillating between gay festivity and dangerous violence, becomes perceptible in elemental and cosmic power. He erupts as fire, water, air or earth, lightning and thunder, earthquakes, storm and sprouting vegetation. He is inebriating wine or ivy and wild dance. Moreover, his chor(a)ic chronotope is located in the Other, in the realm of death, in the marshes, on the shores and in the sea: he must pass through the chora in order to become suddenly present in epiphany.

After I identified briefly the major features of the Bacchic chronotope in the parodos of Bacchae that I had addressed elsewhere, I focused on the fifth stasimon of Antigone, an exemplary tragic song in this regard. Of course, the concept can be applied to many choral songs featuring Dionysus. The concept developed above can open an entire research agenda, but time and place forbids me to pursue the Bacchic chronotope in other instances.

Having given a detailed analysis in a close reading of the fifth stasimon of Antigone, I concluded in giving an account of the web of Dionysiac references and Bacchic patterns that constitute this play. We have seen that Antigone is a most Dionysiac play. The fifth stasimon is thus only the final stage on a circuitous path leading to the catastrophic end. Antigone is connected with the god,

131 Bierl 2001, esp. 140-150 (Engl. 2009, 116-125). 
she acts in his chora of mystic wonder and is interconnected with death. She desires the Other and finally transgresses the boundary to death. Dionysus is, from the very beginning, or latest from the parodos, present in his chora. He continually draws closer to his opponent Creon, changing from potentiality into energetic and elemental power. In this regard, it is logical that the chorus calls for

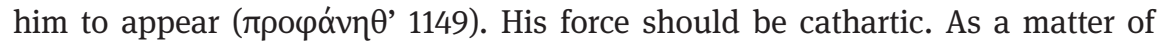
fact, the chorus is caught in the vain hope that the city-god will reverse the grim situation of the diseased polis. But at the same time, the chorus, as authoritative voice, says typically the right thing, too. It envisages the god arriving in a pompe that he welcomes himself as the notional chorus leader.

The Bacchic chronotope is a whirl of concentric choruses extending even to the cosmic level. In this regard, the chronotope is highly metatragic and a powerful mise en abyme, since it references back to the choral performance executed in honour of Dionysus and displayed in the orchestra of the Athenian theatre of Dionysus. The god thus becomes epiphanic in the orchestra, in the here and now, but also somehow in the mimetically produced world of the mythic past. Present in dance and performativity, he remains absent in presence. After passing through the chora he is transformed into an energetic force, to fire, that will take revenge on Creon. All things considered, the Bacchic chronotope, the special configuration of space and time, is a vital element to understand texts performed in a Dionysian context and occasion.

\section{Bibliography}

Alexiou, M. 2002. After Antiquity. Greek Language, Myth, and Metaphor. Ithaca and London. Bakhtin, M.M. 1981. The Dialogic Imagination. Translated by C. Emerson and M. Holquist. Austin.

Beil, U.J. 2007. Bedecken, Beflecken, Beschwören. Präsenzeffekte in der Antigone des Sophokles. In Kiening 2007b, 147-178.

Bernabé, A. 2005. Poetae epici Graeci. Testimonia et fragmenta. Pars II. Fasc. 2: Orphicorum et Orphicis similium testimonia et fragmenta. Munich and Leipzig (= Bernabé).

Bierl, A. 1989. Was hat die Tragödie mit Dionysos zu tun? Rolle und Funktion des Gottes am Beispiel der Antigone des Sophokles. WJA 15: 43-58.

Bierl, A.F.H. 1991. Dionysos und die griechische Tragödie. Politische und 'metatheatralische' Aspekte im Text. Tübingen.

Bierl, A. 2001. Der Chor in der Alten Komödie. Ritual und Performativität (unter besonderer Berücksichtigung von Aristophanes' Thesmophoriazusen und der Phalloslieder fr. 851 PMG). Munich and Leipzig 2001 (see the revised second English edition Bierl 2009).

Bierl, A. 2006. Räume im Anderen und der griechische Liebesroman des Xenophon von Ephesos. Träume? In Mensch und Raum von der Antike bis zur Gegenwart, ed.

A. Loprieno (Colloquium Rauricum 9), 71-103. Munich and Leipzig (see the revised second English edition Bierl 2014). 
Bierl, A. 2007. Mysterien der Liebe und die Initiation Jugendlicher. Literatur und Religion im griechischen Roman. In Literatur und Religion, II. Wege zu einer mythisch-rituellen Poetik bei den Griechen, eds. A. Bierl, R. Lämmle and K. Wesselmann, 239-334. Berlin and New York.

Bierl, A. 2009. Ritual and Performativity. The Chorus in Old Comedy. Translated by Alex Hollmann. Washington, DC and Cambridge, MA.

Bierl, A. 2011a. Dionysos auf der Bühne: Gattungsspezifische Aspekte des Theatergottes in Tragödie, Satyrspiel und Komödie. In Schlesier 2011, 315-341.

Bierl, A. 2011b. Prozessionen auf der griechischen Bühne: Performativität des einziehenden Chors als Manifestation des Dionysos in der Parodos der Euripideischen Bakchen. In Medialität der Prozession. Performanz ritueller Bewegung in Texten und Bildern der Vormoderne. Médialité de la procession. Performance du mouvement rituel en textes et en images à l'époque pré-moderne, eds. K. Gvozdeva and H.R. Velten, 35-61. Heidelberg.

Bierl, A. 2012. Dionysos' Epiphany in Performance. The God of Ecstatic Cry, Noise, Song, Music, and Choral Dance. In Dionysus: Myth, Cult, Ritual. Electra 2: 1-12 online publication (published April 2013) http://electra.lis.upatras.gr/index.php/electra/index

Bierl, A. 2013a. Maenadism as Self-Referential Chorality in Euripides' Bacchae. In Gagné and Hopman 2013a, 211-226.

Bierl, A. 2013b. Der vielnamige Dionysos. Wesen und Funktion des Gottes im Spiegel seiner Beinamen. In Dionysos. Rausch und Ekstase, ed. M. Philipp (Catalogue of the Exhibition, Bucerius Kunst Forum Hamburg and Staatliche Kunstsammlungen Dresden 2013/2014), 30-39. Munich.

Bierl, A. 2014. Space in Xenophon of Ephesus: Love, Dream, and Dissemination. Publication in electronic form on the CHS-website http://chs.harvard.edu/CHS/article/display/5637

Blech, M. 1982. Studien zum Kranz bei den Griechen (RGVV 38). Berlin.

Boedeker, D.D. 1974. Aphrodite's Entry into Greek Epic (Mnemosyne, Suppl. 31). Leiden.

Bohrer, K.-H. 2015. Das Erscheinen des Dionysos. Antike Mythologie und moderne Metapher. Berlin.

Borgeaud, P. 2005. D’Antigone à Erigone. In Antigone et le devoir de sépulture, ed. S. Muriel, 44-58. Geneva.

Brown, A. 1987. Sophocles. Antigone. Edited with translation and notes. Warminster.

Buchan, M. 2012. Sophocles with Lacan. In A Companion to Sophocles, ed. K. Ormand, 492-504. Malden, MA and Oxford.

Burkert, W. 1983. Homo Necans. The Anthropology of Ancient Greek Sacrificial Ritual and Myth. Translated by P. Bing. Berkeley, Los Angeles and London.

Burkert, W. 1987. Ancient Mystery Cults. Cambridge, MA.

Burton, R.W.B. 1980. The Chorus in Sophocles' Tragedies. Oxford.

Casadio, G. 1994. Dioniso italiota. Un dio greco in Italia meridionale. AION (filol.) 16: 79-104.

Casey, E. 1997. The Fate of Place. A Philosophical Journey. Berkeley and Los Angeles. Chantraine, P. 1968. La formation des noms en grec ancien. Revised edition. Paris. Copley, F.O. 1937. The Pathetic Fallacy in Early Greek Poetry. AJPh 58: 194- 209.

Csapo, E. 1999/2000. Later Euripidean Music. ICS 24-25: 399-426. 
Csapo, E. 2008. Star Choruses: Eleusis, Orphism, and New Musical Imagery and Dance. In Performance, Iconography, Reception: Studies in Honour of Oliver Taplin, eds. M. Revermann and P. Wilson, 262-290. Oxford.

Cullyer, H. 2005. A Wind That Blows from Thrace: Dionysus in the Fifth Stasimon of Sophocles' Antigone. CW 99.1: 3-20.

Cursaru, G. 2014. Xúp $\alpha$ au cœur des enjeux politico-religieux et de la rhétorique patriotique dans les tragédies grecques. Étude de cas: EEdipe à Colone de Sophocle. Mythos n.s. 8: $113-136$

D'Aquili, E.G. and C.D. Laughlin Jr. 1979. The Neurobiology of Myth and Ritual. In The Spectrum of Ritual. A Biogenetic Structural Analysis, eds. E.G. d’Aquili, C.D. Laughlin Jr. and J. McManus, 152-182. New York.

Dawe, R.D. (ed.) 1979. Sophocles: Tragoediae, II. Leipzig.

Derrida, J. 1983. The Principle of Reason: The University in the Eyes of Its Pupils. Diacritics 13.3: $2-20$.

Derrida, J. 1995. On the Name. Edited by T. Dutoit, translated by D. Wood, J.P. Leavey Jr. and I. McLeod. Stanford.

Dodds, E.R. 1960. Euripides. Bacchae. Edited with introduction and commentary. Second edition. Oxford.

Dorsch, K.-D. 1982. Götterhymnen in den Chorliedern der griechischen Tragiker. Form, Inhalt und Funktion. Dissertation Münster.

Dover, K.J. 1993. Aristophanes. Frogs. Edited with introduction and commentary. Oxford.

Eitrem, S. 1915. Opferritus und Voropfer der Griechen und Römer. Christiania.

Ford, A.L. 2011. Dionysos' Many Names in Aristophanes' Frogs. In Schlesier 2011, 343-355.

Förs, H. 1964. Dionysos und die Stärke der Schwachen im Werk des Euripides. Dissertation Tübingen University. Bamberg.

Frank, M. 1982. Der kommende Gott: Vorlesungen über die neue Mythologie. Part 1. Frankfurt a.M.

Furley, W.D. and J.M. Bremer 2001. Greek Hymns, I: The Texts in Translation; II: Greek Texts and Commentary (Studien und Texte zu Antike und Christentum 9-10). Tübingen.

Gagné, R. and M.G. Hopman (eds.) 2013a. Choral Mediations in Greek Tragedy. Cambridge.

Gagné, R. and M.G. Hopman 2013b. Introduction: The Chorus in the Middle. In Gagné and Hopman 2013a, $1-34$.

Gernet, L. 1953. Dionysos et la religion dionysiaque: éléments hérités et traits originaux. REG 66: $377-395$.

Gödde, S. 2011. 'Fremde Nähe'. Zur mythologischen Differenz des Dionysos. In Schlesier 2011, 85-104.

Graf, F. 1974. Eleusis und die orphische Dichtung Athens in vorhellenistischer Zeit (RGVV 33). Berlin.

Graf, F. and S.I. Johnston 2007. An Edition and Translation. In Ritual Texts for the Afterlife. Orpheus and the Bacchic Gold Tablets, eds. F. Graf and S.I. Johnston, 1-49. London and New York (= Graf and Johnston).

Griffith, M. (ed.) 1999. Sophocles. Antigone. Cambridge.

Haß, U. 2014. Die zwei Körper des Theaters. Protagonist und Chor. In Tatari 2014, 139-159.

Haß, U. and M. Tatari 2014. Eine andere Geschichte des Theaters. In Tatari 2014, 77-90.

Heinrich, K. 2002. Der Staub und das Denken. Zur Faszination der Sophokleischen Antigone nach dem Krieg. In Sophokles. Antigone, ed. G. Greve, 25-58. Tübingen. 
Henrichs, A. 1978. Greek Maenadism from Olympias to Messalina. HSPh 82: 121-160.

Henrichs, A. 1982. Changing Dionysiac Identities. In Jewish and Christian Self-Definition, III. Self-Definition in the Graeco-Roman World, eds. B.F. Meyer and E.P. Sanders, 137-160 and 213-236. Philadelphia.

Henrichs, A. 1984. Loss of Self, Suffering, Violence: The Modern View of Dionysus from Nietzsche to Girard. HSPh 88: 205-240.

Henrichs, A. 1990. Between Country and City: Cultic Dimensions of Dionysus in Athens and Attica. In Cabinet of the Muses. Essays on Classical and Comparative Literature in Honor of Thomas G. Rosenmeyer, eds. M. Griffith and D.J. Mastronarde, 257-277. Atlanta.

Henrichs, A. 1994/1995. 'Why Should I Dance?’: Choral Self-Referentiality in Greek Tragedy. Arion Third Series 3.1: 56-111.

Henrichs, A. 1996a. Dionysus. $O C D^{3}: 479-482$.

Henrichs, A. 1996b. Dancing in Athens, Dancing on Delos: Some Patterns of Choral Projection in Euripides. Philologus 140: 48-62.

Henrichs, A. 1996c. "Warum soll ich denn tanzen?". Dionysisches im Chor der griechischen Tragödie (Lectio Teubneriana 4). Stuttgart and Leipzig.

Henrichs, A. 2008. Dionysische Imaginationswelten: Wein, Tanz, Erotik. In Dionysos. Verwandlung und Ekstase, eds. R. Schlesier and A. Schwarzmeier, 19-27. Berlin and Regensburg.

Henrichs, A. 2011. Göttliche Präsenz als Differenz: Dionysos als epiphanischer Gott. In Schlesier 2011, 105-116.

Jakobson, R. 1960. (Closing Statement:) Linguistics and Poetics. In Style in Language, ed. T.A. Sebeok, 350-377. Cambridge, MA (reprint in Roman Jakobson. Selected Writings, III, ed. S. Rudy. The Hague, Paris and New York 1981, 18-51).

Jebb, R.C. 1900. Sophocles. The Plays and Fragments. With critical notes, commentary, and translation in English prose, III: The Antigone. Cambridge.

Jiménez San Cristóbal, A.I. 2013. The Sophoclean Dionysos. In Redefining Dionysos, eds. A. Bernabé, M. Herrero de Jáuregui, A.I. Jiménez San Cristóbal and R. Martín Hernández, $272-300$. Berlin/Boston.

Jouanna, J. 2007. L'hymne chez Sophocle. In L'hymne antique et son public, ed. Y. Lehmann, 109-132. Turnhout.

Kamerbeek, J.C. 1978. The Plays of Sophocles. Commentaries, III: The Antigone. Leiden.

Kavoulaki, А. 1996. ПОМПАІ: Processions in Athenian Tragedy. Dissertation Oxford.

Kavoulaki, A. 1999. Processional Performance and the Democratic Performance. In Performance Culture and Athenian Democracy, eds. S. Goldhill and R. Osborne, 293-320. Cambridge.

Kerényi, K. 1935. Dionysos und das Tragische in der Antigone (Frankfurter Studien 13). Frankfurt a.M.

Kiening, C. 2007a. Mediale Gegenwärtigkeit. Paradigmen - Semantiken - Effekte. In Kiening 2007b, 9-70.

Kiening, C. (ed.) 2007b. Mediale Gegenwärtigkeit. Zurich.

Kitzinger, M.R. 2008. The Choruses of Sophokles' Antigone and Philoktetes. A Dance of Words. Leiden and Boston.

Kowalzig, B. 2007. 'And Now All the World Shall Dance!' (Eur. Bacch. 114). Dionysus' Choroi between Drama and Ritual. In The Origins of Theater in Ancient Greece and Beyond. From Ritual to Drama, eds. E. Csapo and M.C. Miller, 221-251. Cambridge. 
Kramer, K. and J. Dünne 2009. Einleitung. Theatralität und Räumlichkeit. In Theatralität und Räumlichkeit. Raumordnungen und Raumpraktiken im theatralen Mediendispositiv, eds.

J. Dünne, S. Friedrich and K. Kramer, 15-32. Würzburg.

Kristeva, J. 1984. Revolution in Poetic Language. New York.

Lacan, J. 1957. The Instance of the Letter in the Unconscious, or Reason Since Freud. In Lacan 2006, 412-441 (originally published in La Psychoanalyse 3, 1957: 47-81; reprint of the French original in Lacan 1966, 493-528).

Lacan, J. 1966. Écrits. Paris.

Lacan, J. 1992. The Ethics of Psychoanalysis. The Seminar of Jacques Lacan. Ed. J.-A. Miller. Book VII, translated with notes by D. Porter. London (orig. Paris 1986).

Lacan, J. 2006. Écrits. The First Complete Edition in English. Translated by B. Fink. New York and London 2006.

Lonnoy, M.-G. 1985. Arès et Dionysos dans la tragédie grecque: Le rapprochement des contraires. REG 98: 65-71.

Loraux, N. 1987. Tragic Ways of Killing a Woman. Translated by A. Forster. Cambridge. Macedo, J.M. 2011. In between Poetry and Ritual: The Hymn to Dionysus in Sophocles' Antigone (1115-54). CQ 61: 402-411.

McEwen, I.K. 1993. Socrates' Ancestor. An Essay on Architectural Beginnings. Cambridge, MA. McLuhan, M. 1964. Understanding Media. The Extensions of Man. New York (second edition 1966; reissued Cambridge, MA 1994).

Metzger, H. 1944/1945. Dionysos chthonien d'après les monuments figurés de la période classique. BCH 69/69: 296-339.

Miller, P.A. 2007. Lacan's Antigone: The Sublime Object and the Ethics of Interpretation. Phoenix 61.1/2: 1-14.

Moulinier, L. 1952. Le pur et l'impur dans la pensée des Grecs d'Homère à Aristote. Paris. Müller, G. 1967. Sophokles. Antigone. Erläutert und mit einer Einleitung versehen. Heidelberg. Murrey, L. 2015. Hölderlin's Dionysiac Poetry. The Terrifying-Exciting Mysteries. Cham.

Nagy, G. 2013. The Ancient Greek Hero in 24 Hours. Cambridge, MA and London (http://nrs. harvard.edu/urn3:hul.ebook:CHS_NagyG.The_Ancient_Greek_Hero_in_24_Hours.2013).

Nancy, J.-L. 2014. Theater als Kunst des Bezugs. In Tatari 2014, 91-108.

Norden, E. 1913. Agnostos Theos. Untersuchungen zur Formengeschichte religiöser Rede. Leipzig.

Otto, W.F. 1933. Dionysos. Mythos und Kultus. Frankfurt a.M. (seventh edition 2011).

Oudemans, T.C.W. and A.P.M.H. Lardinois 1987. Tragic Ambiguity: Anthropology, Philosophy and Sophocles' Antigone. Leiden.

Polignac, F. de 1995. Cults, Territory, and the Origins of the Greek City-State. Translated by J. Lloyd, foreword by C. Mossé. Chicago and London (orig. Paris 1984).

Powell, J.U. 1925. Collectanea Alexandrina. Oxford (reprint Chicago 1981).

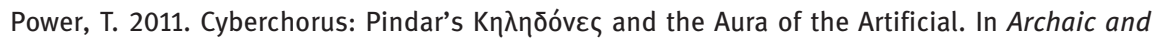
Classical Choral Song. Performance, Politics and Dissemination, eds. L. Athanassaki and E. Bowie (Trends in Classics, Suppl. 10), 67-113. Berlin and New York.

Randhawa, B.P. 2014. The Unblest Room: Kristeva's Chora in Sophocles's Antigone. Philosophy and Literature 38: 293-313.

Rickert, T. 2007. Toward the Chôra: Kristeva, Derrida, and Ulmer on Emplaced Invention. Philosophy and Rhetoric 40: 251-273.

Rodighiero, A. 2012. Generi lirico-corali nella produzione drammatica di Sofocle. Tübingen. 
Rohdich, H. 1980. Antigone. Beitrag zu einer Theorie des Sophokleischen Helden. Heidelberg. Sallis, J. 1999. Chorology: On Beginning in Plato's Timaeus. Bloomington.

Schlesier, R. 1997. Dionysos I. Religion. DNP 3: 651-662.

Schlesier, R. (ed.) 2011. A Different God? Dionysos and Ancient Polytheism. Berlin and Boston.

Scullion, S. 1998. Dionysos and Katharsis in Antigone. ClAnt 17: 96-122.

Seaford, R. 1987. The Tragic Wedding. JHS 107: 106-130.

Seaford, R. 2012. Cosmology and the Polis. The Social Construction of Space and Time in the Tragedies of Aeschylus. Cambridge.

Segal, C. 1981. Tragedy and Civilization. An Interpretation of Sophocles. Cambridge, MA and London.

Segal, C. 1982. Dionysiac Poetics and Euripides' Bacchae. Princeton (expanded second edition with a new afterword by the author, 1997).

Segal, C. 1983. Greek Myth as Semiotic and Structural System and the Problem of Tragedy. Arethusa 16(1-2): 173-198.

Segal, C. 1986. Interpreting Greek Tragedy: Myth, Poetry, Text. Ithaca, NY.

Sourvinou-Inwood, C. 1989. Assumptions and the Creating of Meaning: Reading Sophocles' Antigone. JHS 109: 134-148.

Tambiah, S.J. 1985. Culture, Thought, and Social Action. An Anthropological Perspective. Cambridge, MA and London.

Tatari, M. (ed.) 2014. Orte des Unermesslichen. Theater nach der Geschichtsteleologie. Zurich and Berlin.

Turner, V. 1974. Dramas, Fields, and Metaphors. Symbolic Action in Human Society. Ithaca and London.

Vernant, J.-P. 1965. Mythe et pensée chez les Grecs. Études de psychologie historique. Paris; cited after third new edition, revised and enlarged, 1985.

Vernant, J.-P. 1981. Le dieu de la fiction tragique. In Vernant and Vidal-Naquet 1986, 17-24.

Vernant, J.-P. (with F. Frontisi-Ducroux) 1983. Figures du masque en Grèce ancienne. In Vernant and Vidal-Naquet 1986, 25-43 (originally published in Journal de Psychologie 1/2, 1983: 53-69).

Vernant, J.-P. 1985. Le Dionysos masqué des Bacchantes d'Euripide. In Vernant and Vidal-Naquet 1986, 237-270 (originally published in L'Homme 93, 1985: 31-58).

Vernant, J.-P. 1986. Conclusion. In L'association dionysiaque dans les sociétés anciennes (Collection de l'École Française de Rome 89), 291-303. Rome.

Vernant, J.-P. and P. Vidal-Naquet (eds.) 1986. Mythe et tragédie en Grèce ancienne, II. Paris. Versnel, H.S. 1970. Triumphus. An Inquiry into the Origin, Development and Meaning of the Roman Triumph. Leiden.

Versnel, H.S. 1972. IAKXOE: Some Remarks Suggested by an Unpublished Lekythos in the Villa Giulia. TAMANTA 4: 23-38.

Vicaire, P. 1968. Place et figure de Dionysos dans la tragédie de Sophocle. REG 81: 351-373. Wiles, D. 2003. A Short History of Western Performance Space. Cambridge.

Winnington-Ingram, R.P. 1980. Sophocles: An Interpretation. Cambridge.

Zeitlin, F.I. 1990. Playing the Other: Theater, Theatricality, and the Feminine in Greek Drama. In Nothing to Do with Dionysos? Athenian Drama in Its Social Context, eds. J.J. Winkler and F.I. Zeitlin, 63-96. Princeton. 
Zeitlin, F.I. 1993. Staging Dionysus between Thebes and Athens. In Masks of Dionysus, eds. T.H. Carpenter and C.A. Faraone, 147-182. Ithaca and London. 